medRxiv preprint doi: https://doi.org/10.1101/2021.02.16.21251535; this version posted August 25, 2021. The copyright holder for this preprint (which was not certified by peer review) is the author/funder, who has granted medRxiv a license to display the preprint in perpetuity.

It is made available under a CC-BY-NC-ND 4.0 International license.

\title{
Viral dynamics of SARS-CoV-2 variants in vaccinated and unvaccinated individuals
}

Stephen M. Kissler*1, Joseph R. Fauver², Christina Mack³,4, Caroline G. Tai ${ }^{3}$, Mallery I.

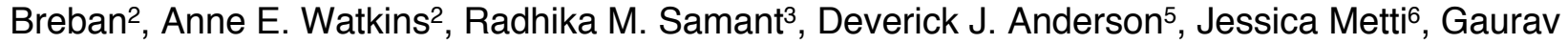
Khullar, Rachel Baits ${ }^{6}$, Matthew MacKay ${ }^{6}$, Daisy Salgado', ${ }^{6}$ Tim Baker ${ }^{6}$, Joel T. Dudley ${ }^{6}$, Christopher E. Mason ${ }^{6}$, David D. Ho7 , Nathan D. Grubaught2, Yonatan H. Grad¹

1 Department of Immunology and Infectious Diseases, Harvard T.H. Chan School of Public Health, Boston, MA

2 Department of Epidemiology of Microbial Diseases, Yale School of Public Health, New Haven, CT

3 IQVIA, Real World Solutions, Durham, NC

4 Department of Epidemiology, University of North Carolina-Chapel Hill, Chapel Hill, NC

5 Duke Center for Antimicrobial Stewardship and Infection Prevention, Durham, NC

6 TEMPUS Labs, Chicago, IL

7 Aaron Diamond AIDS Research Center, Columbia University Vagelos College of Physicians and Surgeons, New York, NY

* denotes equal contribution

† denotes co-senior authorship

Correspondence and requests for materials should be addressed to:

Email: ygrad@hsph.harvard.edu

Telephone: 617.432 .2275 
medRxiv preprint doi: https://doi.org/10.1101/2021.02.16.21251535; this version posted August 25, 2021. The copyright holder for this preprint (which was not certified by peer review) is the author/funder, who has granted medRxiv a license to display the preprint in perpetuity.

It is made available under a CC-BY-NC-ND 4.0 International license .

\section{Abstract.}

Background. The alpha and delta SARS-CoV-2 variants have been responsible for major recent waves of COVID-19 despite increasing vaccination rates. The reasons for the increased transmissibility of these variants and for the reduced transmissibility of vaccine breakthrough infections are unclear.

Methods. We quantified the course of viral proliferation and clearance for 173 individuals with acute SARS-CoV-2 infections using longitudinal quantitative RT-PCR tests conducted using anterior nares/oropharyngeal samples $(n=199,941)$ as part of the National Basketball Association's (NBA) occupational health program between November $28^{\text {th }}, 2020$, and August $11^{\text {th }}, 2021$. We measured the duration of viral proliferation and clearance and the peak viral concentration separately for individuals infected with alpha, delta, and non-variants of interest/variants of concern (non-VOI/VOC), and for vaccinated and unvaccinated individuals.

Results. The mean viral trajectories of alpha and delta infections resembled those of nonVOI/VOC infections. Vaccine breakthrough infections exhibited similar proliferation dynamics as infections in unvaccinated individuals (mean peak Ct: $20.5,95 \%$ credible interval $[19.0,21.0]$ vs. 20.7 [19.8, 20.2], and mean proliferation time 3.2 days [2.5, 4.0] vs. 3.5 days [3.0, 4.0]); however, vaccinated individuals exhibited faster clearance (mean clearance time: 5.5 days $[4.6,6.6]$ vs. 7.5 days $[6.8,8.2])$.

Conclusions. Alpha, delta, and non-VOI/VOC infections feature similar viral trajectories. Acute infections in vaccinated and unvaccinated people feature similar proliferation and peak Ct, but vaccinated individuals cleared the infection more quickly. Viral concentrations do not fully explain the differences in infectiousness between SARS-CoV-2 variants, and mitigation measures are needed to limit transmission from vaccinated individuals. 
medRxiv preprint doi: https://doi.org/10.1101/2021.02.16.21251535; this version posted August 25, 2021. The copyright holder for this preprint (which was not certified by peer review) is the author/funder, who has granted medRxiv a license to display the preprint in perpetuity.

It is made available under a CC-BY-NC-ND 4.0 International license .

Two opposing forces shaping the COVID-19 pandemic are (1) the emergence of increasingly transmissible SARS-CoV-2 variants of concern (VOCs) and (2) the uptake of vaccines that prevent infection, protect against severe disease, and reduce transmission. Among the VOCs, of special interest are the alpha (lineage B.1.1.7) and delta (B.1.617.2, AY.1, AY.2, AY.3, and AY.3.1) variants, responsible for recent waves of COVID-19. ${ }^{1}$ These variants feature mutations in the spike protein receptor binding domain ${ }^{2}$ that may enhance ACE-2 binding, ${ }^{3}$ thus increasing the efficiency of virus transmission. In addition to, and perhaps due to, these attributes, the viral trajectories for infections with alpha and delta could feature a higher peak viral load or longer duration of carriage, both of which could increase transmissibility. Meanwhile, preliminary evidence suggests that individuals with vaccine breakthrough infections are less likely to transmit, 4,5 but whether this is attributable to lower peak viral loads, shorter duration of carriage, or both, remains uncertain.

By measuring viral concentration over the course of acute infection, it is possible to inform hypotheses about the mechanisms that underlie variation in transmissibility. Recent evidence suggests that delta-variant infections may feature substantially higher peak viral concentrations relative to other lineages, ${ }^{6}$ while viral concentrations in alpha-variant infections were indistinguishable from non-variant infections. ${ }^{7}$ Vaccinated individuals who become infected with SARS-CoV-2 may clear their infections more quickly than unvaccinated individuals, ${ }^{8}$ and vaccine breakthrough infections with delta may feature similar peak viral concentrations as non-breakthrough delta infections. ${ }^{9}$ However, many of these studies rely on cross-sectional viral concentration measurements triggered by the onset of symptoms, which miss viral dynamics during the critical early stages of infection. Furthermore, population transmission dynamics can bias cross-sectional viral concentration measurements, ${ }^{10}$ making it difficult to compare viral concentrations between variants that emerged at different periods of the pandemic.

To overcome these limitations, we collected and analyzed a prospective, longitudinal set of SARS-CoV-2 viral samples from 173 individuals obtained as part of the National Basketball Association's occupational health program. Using a Bayesian hierarchical statistical model, we compared SARS-CoV-2 viral dynamics between individuals infected with alpha, delta, and non-variants of interest/variants of concern (non-VOI/VOCs) as well as for vaccinated and unvaccinated individuals. 
medRxiv preprint doi: https://doi.org/10.1101/2021.02.16.21251535; this version posted August 25, 2021. The copyright holder for this preprint (which was not certified by peer review) is the author/funder, who has granted medRxiv a license to display the preprint in perpetuity.

It is made available under a CC-BY-NC-ND 4.0 International license .

\section{Methods.}

Study design. The data reported here represent a convenience sample including team staff, players, arena staff, and other vendors (e.g., transportation, facilities maintenance, and food preparation) affiliated with the National Basketball Association (NBA). The study period ran between November $28^{\text {th }}, 2020$, and August $11^{\text {th }}, 2021$. Clinical samples were obtained by combined swabs of the anterior nares and oropharynx administered by a trained provider. Viral concentration was measured using the cycle threshold $(\mathrm{Ct})$ according to the Roche cobas target 1 assay. Ct values were converted to viral genome equivalents using a standard curve (Supplementary methods).

Study oversight. In accordance with the guidelines of the Yale Human Investigations Committee, this work with de-identified samples was approved for research not involving human subjects by the Yale Institutional Review Board (HIC protocol \# 2000028599). This project was designated exempt by the Harvard Institutional Review Board (IRB20-1407).

Study participants. Out of an initial pool of 872 participants who tested positive for SARS-CoV-2 infection during the study period, 173 individuals (90\% male) had clinically confirmed novel infections that met our inclusion criteria: at least three positive PCR tests $(\mathrm{Ct}<40)$, at least one negative PCR test $(\mathrm{Ct}=40)$, and at least one test with $\mathrm{Ct}<32$ with the first positive test $(\mathrm{Ct}<40)$ occurring before August $1^{\text {st }}$ to ensure full sampling of the trajectory before the end of the study period. (Table 1). A total of 19,941 samples were available for this cohort, averaging 548 samples per week. Of the individuals who met the inclusion criteria, 36 were infected with alpha (B.1.1.7) and 36 with delta (B.1.617.2, AY.1, AY.2, AY.3, or AY.3.1), as confirmed by sequencing. An additional 28 individuals were infected with other variants of interest/variants of concern. There were 37 individuals with vaccine breakthrough infections, defined as infections for which the first positive test occurred at least two weeks after receipt of the final dose. Of these, 23 received the Pfizer-BioNTech vaccine, 8 received the Johnson \& Johnson/Janssen vaccine, and 3 received the Moderna vaccine. The vaccine manufacturer was not reported for the remaining 3 individuals.

Study outcomes. We quantified the viral proliferation duration (time from first possible detection to peak viral concentration) the viral clearance duration (time from peak viral concentration to clearance of acute infection), the duration of acute infection (proliferation duration plus clearance 
medRxiv preprint doi: https://doi.org/10.1101/2021.02.16.21251535; this version posted August 25, 2021. The copyright holder for this preprint (which was not certified by peer review) is the author/funder, who has granted medRxiv a license to display the preprint in perpetuity.

It is made available under a CC-BY-NC-ND 4.0 International license .

duration), and the peak viral concentration for each person. We also quantified the population mean values of these quantities separately for individuals infected with alpha $(n=36)$, delta $(n=$ $36)$, and non-VOI/VOCs $(n=41)$, as well as for vaccinated $(n=37)$ and unvaccinated $(n=136)$ individuals.

Genome sequencing and lineage assignments. RNA was extracted and confirmed as SARS-CoV2 positive by RT-qPCR with the Thermo Fisher TaqPath SARS-CoV-2 assay. ${ }^{11}$ Next Generation Sequencing with the Illumina COVIDSeq ARTIC primer set ${ }^{12}$ was used for viral amplification. Library preparation was performed using the amplicon-based Illumina COVIDseq Test v03 ${ }^{13}$ and sequenced $2 \times 74$ on Illumina NextSeq 550 following the protocol as described in Illumina's documentation. ${ }^{14}$ The resulting FASTQs were processed and analyzed on Illumina BaseSpace Labs using the Illumina DRAGEN COVID Lineage Application; ${ }^{15}$ versions included are 3.5.0, 3.5.1, 3.5.2, and 3.5.3. The DRAGEN COVID Lineage pipeline was run with default parameters recommended by Illumina. Samples were considered SARS-COV-2 positive if at least 5 viral amplicon targets were detected at 20x coverage. Each SARS-COV-2 positive sample underwent lineage assignment and phylogenetics analysis using the most updated version of Pangolin ${ }^{16}$ and NextClade, ${ }^{17}$ respectively.

Statistical analysis. Following previously described methods, ${ }^{18}$ we used a Bayesian hierarchical model to estimate the proliferation duration, clearance duration, and peak viral concentration for each person and for the sub-populations of interest. The model describes the $\log _{10}$ viral concentration during an acute infection using a continuous piecewise-linear curve with control points that specify the time of acute infection onset, the time and magnitude of peak viral concentration, and the time of acute infection clearance. The assumption of piecewise linearity is equivalent to assuming exponential viral growth during the proliferation period followed by exponential viral decay during the clearance period. The control points were inferred using the Hamiltonian Monte Carlo algorithm as implemented in Stan (version 2.24). ${ }^{19}$ We used priors informed by a previous analysis ${ }^{18}$ for the main analysis and conducted a sensitivity analysis using vague priors as well as a strongly biased set of priors to assess robustness to the choice of prior. Full details are given in the Supplementary methods. Data and code are available online. ${ }^{20}$

\section{Results.}


medRxiv preprint doi: https://doi.org/10.1101/2021.02.16.21251535; this version posted August 25, 2021. The copyright holder for this preprint (which was not certified by peer review) is the author/funder, who has granted medRxiv a license to display the preprint in perpetuity.

It is made available under a CC-BY-NC-ND 4.0 International license .

Summary of viral concentration measurements and model fit. A median of 6 samples (IQR: [4, 9]) with $\mathrm{Ct}$ values that surpassed the limit of detection $(\mathrm{Ct}=40)$ were recorded for each person. The raw viral concentration measurements are depicted in Figure 1 for individuals infected with alpha, delta, and non-VOI/VOCs as well as for unvaccinated and vaccinated infected individuals. Many of the tail samples depicted in Figure 1 reflect samples with high Ct value/low viral concentration after the conclusion of acute infection. As these were not the main object of study in this analysis, any tests that occurred after the conclusion of an individual's acute infection (as specified by the statistical model) are depicted in lighter shades. Visually, the trajectories appear similar across variants and vaccination statuses. While there are fewer low-level positives following acute infection for those with vaccine breakthrough and delta infections, this may reflect the fact that delta and breakthrough infections were more likely to occur near the end of the study period, which may have led to censoring of these points, as well as the substantial overlap in these categories (see Table 1). The individual-level model fits are depicted Supplementary Figures 1-9. The Gelman R-hat statistic ${ }^{21}$ was less than 1.1 for all parameters, indicating good convergence. There were no divergent iterations, indicating good exploration of the parameter space.

Viral trajectories by variant. We found no difference in the mean peak viral concentration, proliferation duration, clearance duration, or duration of acute infection for alpha or delta relative to non-VOI/VOCs, as evidenced by overlapping 95\% credible intervals (Figure 2A-F, Supplementary Table 1). However, delta infections featured more frequent low peak $\mathrm{Ct}$ values, and corresponding high peak viral concentrations, than alpha or non-VOI/VOC infections, with $13.0 \%$ of the posterior delta trajectories surpassing a Ct value of $15\left(9.6 \log _{10}\right.$ RNA copies $\left./ \mathrm{ml}\right) v s .6 .9 \%$ and $10.2 \%$ of the posterior alpha and non-VOI/VOC trajectories surpassing the same threshold (Figure $\mathbf{2 G}$ ). For those infected with delta, there is some evidence that vaccinated individuals tended to clear the virus more quickly than unvaccinated individuals (mean 5.9 days (95\% credible interval $[4.8,7.2])$ in vaccinated individuals vs. 7.6 days $[5.5,10.1]$ in unvaccinated individuals; Supplementary Figure 10), though the sample sizes are small and the 95\% credible intervals for the mean clearance duration overlap.

Viral trajectories by vaccination status. We found no difference in the mean peak viral concentration or proliferation duration between vaccinated and unvaccinated individuals as evidenced by overlapping 95\% credible intervals (Figure 3). However, breakthrough infections featured a faster clearance time (mean 5.5 days $[4.6,6.5]$ vs. 7.5 days $[6.8,8.2]$ in unvaccinated individuals), 
medRxiv preprint doi: https://doi.org/10.1101/2021.02.16.21251535; this version posted August 25, 2021. The copyright holder for this preprint (which was not certified by peer review) is the author/funder, who has granted medRxiv a license to display the preprint in perpetuity.

It is made available under a CC-BY-NC-ND 4.0 International license .

leading to a shorter overall duration of infection $(8.7$ days $[7.6,9.9]$ in vaccinated individuals vs. 11.0 days $[10.3,11.8]$ in unvaccinated individuals). We found no difference in viral trajectories for infected individuals who received the Pfizer-BioNTech vaccine $(n=23)$ vs. the Johnson \& Johnson/Janssen vaccine ( $n=8$; Supplementary Figure 11). We did not assess viral trajectories for breakthrough infections in individuals who received the Moderna vaccine due to the small sample size $(n=3)$.

\section{Discussion.}

With the emergence of more transmissible SARS-CoV-2 variants such as alpha and delta, a key goal has been to understand which factors contribute to increased transmissibility. Our results indicate that the viral dynamics of infections caused by the alpha variant resemble those caused by the founding SARS-CoV-2 lineages, with similar proliferation and clearance times and similar peak viral concentrations. Viral dynamics in the oropharynx and nasopharynx therefore do not explain the elevated transmissibility of the alpha variant relative to the founding SARS-CoV-2 lineages. ${ }^{22}$ Instead, other factors, such as enhanced receptor binding which could lower the viral dose required for infection, may contribute to the alpha variant's increased transmissibility. The viral dynamics of the delta variant are similar, with the exception that infections caused by the delta variant appear more likely to feature high peak viral concentrations. It is unclear if the greater proportion of cases with high peak viral concentrations reflects the underlying biology of the delta variant, the limited number of cases and sampling, or other factors, including the higher fraction of delta infections that were in vaccinated individuals. Infections with unusually high peak viral concentration may play an outsize role in spreading the virus, either by increasing the risk of transmission outside of close-contact settings ${ }^{23}$ or increasing the likelihood of "superspreading" events, pointing towards a possible mechanism for the enhanced transmissibility of the delta variant. Upper respiratory viral concentrations also do not explain the possible enhanced pathogenicity of the alpha and delta variants. ${ }^{24}$ Further studies are needed to uncover the origins of any differences in virulence, which could stem from differences in systemic viral dynamics that are not captured by oropharyngeal/nasopharyngeal samples.

A second key objective is to define the impact of COVID-19 vaccines on viral dynamics. Strong evidence demonstrates that each of the vaccines used by individuals in this cohort-the Pfizer/BioNTech, Moderna, and Johnson \& Johnson/Janssen vaccines-reduces the rates of symptomatic COVID-19. ${ }^{25-27}$ A growing body of data also suggests that these vaccines reduce rates of 
medRxiv preprint doi: https://doi.org/10.1101/2021.02.16.21251535; this version posted August 25, 2021. The copyright holder for this preprint (which was not certified by peer review) is the author/funder, who has granted medRxiv a license to display the preprint in perpetuity.

It is made available under a CC-BY-NC-ND 4.0 International license .

asymptomatic infection. ${ }^{28-30}$ The extent to which infected vaccinated people can transmit SARSCoV-2 has been unclear, with recent data supporting that breakthrough infections are infectious. ${ }^{9}$ Our data and a recent report from Singapore ${ }^{8}$ show that vaccine breakthrough cases follow a similar proliferation phase and reach similar peak viral concentrations as unvaccinated cases, but have a more rapid clearance phase, thereby modestly shortening the overall duration of infection. If the Ct values in vaccinated and unvaccinated infected individuals reflect the same amounts of infectious virus, then this implies that individuals with breakthrough infections may be as infectious as unvaccinated individuals in the early stage of the infection, but remain infectious for a shorter time, reducing the total degree of onward transmission. These findings are in keeping with the hypothesis that vaccination protects against the severe manifestations of disease but offers less protection against infection in the upper airway. Precautions are therefore necessary to prevent onward transmission even from vaccinated individuals.

Our ability to detect differences in SARS-CoV-2 viral dynamics between key populations was limited by small sample sizes and a high degree of interpersonal variation. More prospective longitudinal testing data within diverse cohorts is urgently needed to help resolve these patterns, particularly the peak viral concentration distribution for delta infections. The participants in this study were predominately young, male, and healthy, and therefore not representative across the general population. This underscores the need for similar studies in more diverse cohorts. Symptoms were not tracked throughout infection in this observational cohort; we were unable to assess differences in viral dynamics between symptomatic and asymptomatic individuals, nor were we able to link the timing of symptoms with key points in the viral trajectories. We did not test for the presence of infectious virus. While high viral concentrations are associated with elevated infectiousness, ${ }^{31}$ the nature of this association may be influenced by multiple factors, including variant, vaccination status, immune function, and host genetics. ${ }^{32}$ Viral culture studies and patient data would therefore help to contextualize the findings presented in this study.

This study provides a detailed picture of acute SARS-CoV-2 viral dynamics for key variants of concern in vaccinated and unvaccinated individuals. Frequent longitudinal measurements of viral concentrations can play a valuable role in illuminating factors contributing to SARS-CoV-2 transmissibility and the nature and extent of the impact of vaccination on viral dynamics in acute infections, thus informing interventions needed to mitigate the impact of COVID-19. 


\begin{tabular}{|c|c|c|c|c|c|c|}
\hline & Alpha (\%) & Delta (\%) & $\begin{array}{l}\text { Other } \\
\text { VOI/VVOC (\%) }\end{array}$ & $\begin{array}{l}\text { Non- } \\
\text { VOIVOC } \\
\text { (\%) }\end{array}$ & $\begin{array}{l}\text { Not } \\
\text { genotyped } \\
\text { (\%) }\end{array}$ & Total (\%) \\
\hline Total & $36(20.8)$ & $36(20.8)$ & 28 (16.2) & $41(23.7)$ & $32(18.5)$ & $173(100)$ \\
\hline \multicolumn{7}{|l|}{ Age } \\
\hline$<18$ & $3(1.7)$ & $2(1.2)$ & $2(1.2)$ & $0(0)$ & $1(0.6)$ & $8(4.6)$ \\
\hline $18-29$ & 23 (13.3) & $6(3.5)$ & $13(7.5)$ & $26(15)$ & $11(6.4)$ & $79(45.7)$ \\
\hline $30-39$ & $4(2.3)$ & $8(4.6)$ & $6(3.5)$ & $7(4.0)$ & $6(3.5)$ & $31(17.9)$ \\
\hline $40-49$ & $4(2.3)$ & $14(8.1)$ & $4(2.3)$ & $3(1.7)$ & $5(2.9)$ & 30 (17.3) \\
\hline $50-59$ & $2(1.2)$ & $4(2.3)$ & $1(0.6)$ & $2(1.2)$ & $4(2.3)$ & $13(7.5)$ \\
\hline$\geq 60$ & $0(0)$ & $2(1.2)$ & $2(1.2)$ & $3(1.7)$ & $5(2.9)$ & 12 (6.9) \\
\hline \multicolumn{7}{|c|}{$\begin{array}{l}\text { Symptoms } \\
\text { reported }\end{array}$} \\
\hline No & 18 (10.4) & 23 (13.3) & $15(8.7)$ & $22(12.7)$ & 24 (13.9) & $102(59.0)$ \\
\hline Yes & $18(10.4)$ & $13(7.5)$ & $13(7.5)$ & $19(11.0)$ & $8(4.6)$ & $71(41.0)$ \\
\hline \multicolumn{7}{|c|}{$\begin{array}{l}\text { Vaccine } \\
\text { breakthrough }\end{array}$} \\
\hline No & 32 (18.5) & $11(6.4)$ & $25(14.5)$ & $41(23.7)$ & 27 (15.6) & $136(78.6)$ \\
\hline Yes & $4(2.3)$ & $25(14.5)$ & $3(1.7)$ & $0(0)$ & $5(2.9)$ & $37(21.4)$ \\
\hline
\end{tabular}

Table 1. Characteristics of the study population. Number and percent (in parentheses) of individuals variant. 
medRxiv preprint doi: https://doi.org/10.1101/2021.02.16.21251535; this version posted August 25, 2021. The copyright holder for this preprint (which was not certified by peer review) is the author/funder, who has granted medRxiv a license to display the preprint in perpetuity.

It is made available under a CC-BY-NC-ND 4.0 International license .

A)

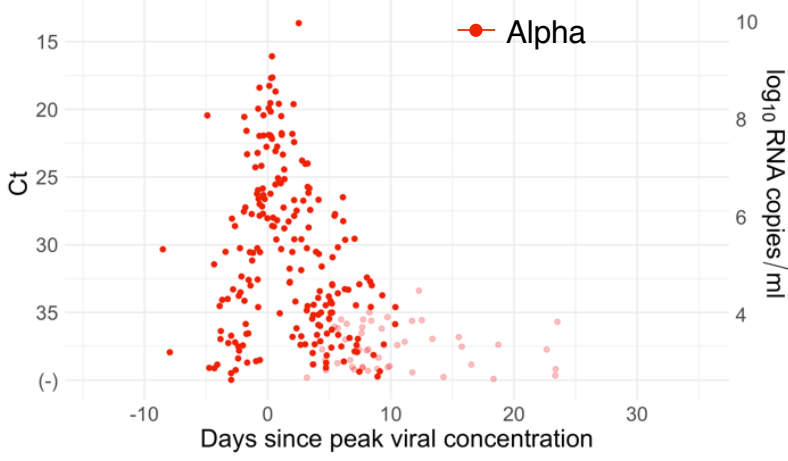

B)

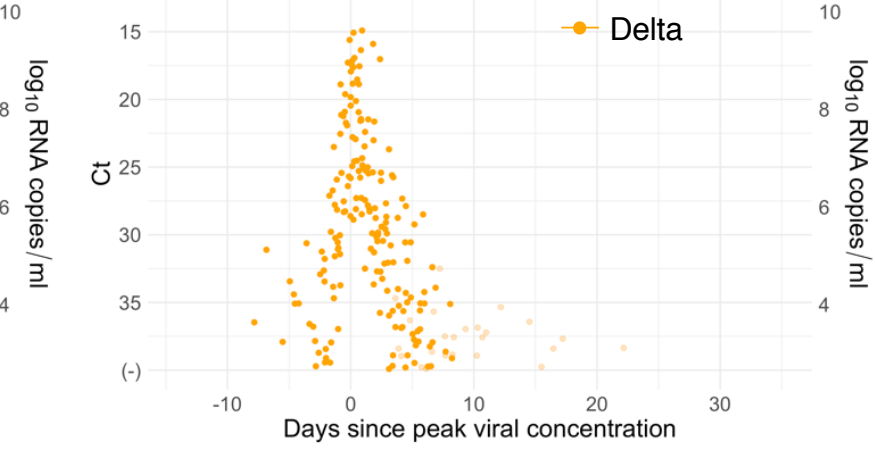

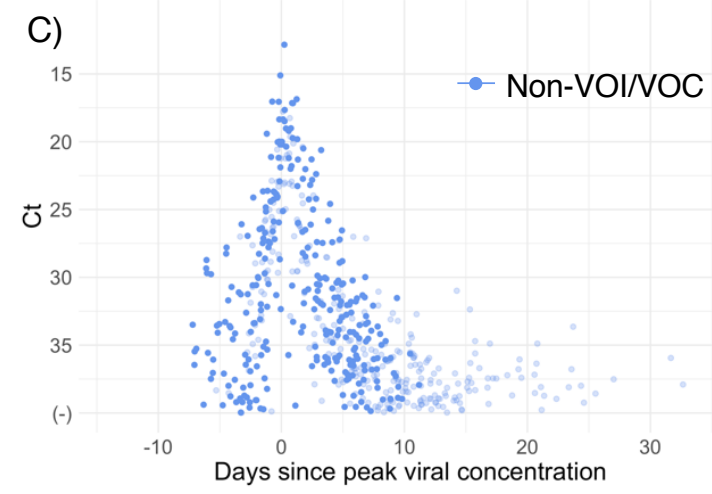

E)

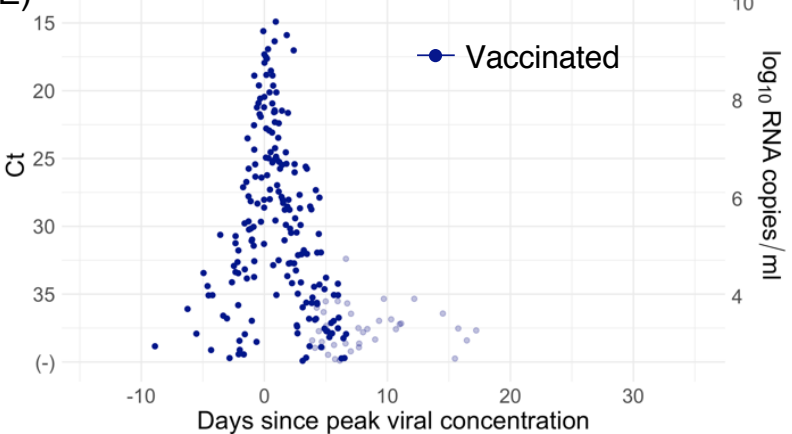

D)

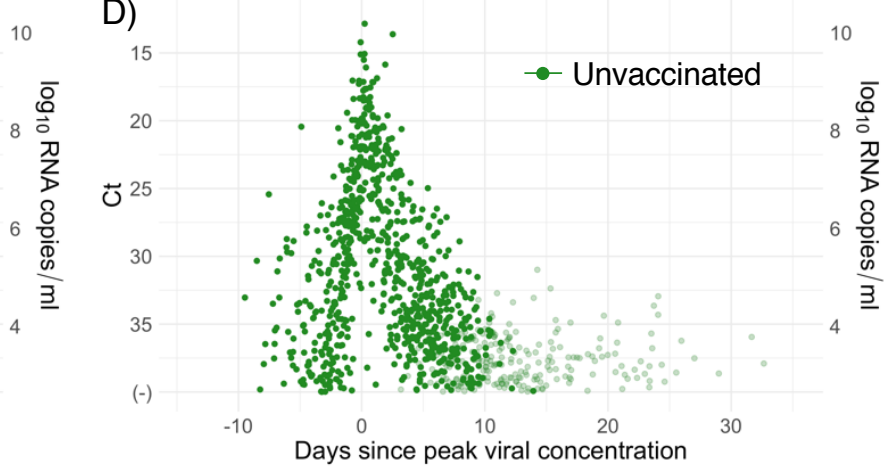

Figure 1. Raw Ct values by variant and vaccination status. Raw $\mathrm{Ct}$ values (points) for individuals infected with (A) alpha, (B) delta, or (C) non-VOI-VOCs, and for (D) unvaccinated and (E) vaccinated individuals. Points are horizontally aligned so that the inferred mean peak viral concentration for each person occurs at time 0 . Points that fall after the conclusion of an individual's acute infection, as measured by the individual's mean posterior infection clearance time, are partially transparent, as these were not the focus of our study. The inset illustrates the process of making the tail points transparent: black points depict viral concentration measurements for a single person and the solid black lines depict the individual's mean posterior viral trajectory. 
medRxiv preprint doi: https://doi.org/10.1101/2021.02.16.21251535; this version posted August 25, 2021. The copyright holder for this preprint (which was not certified by peer review) is the author/funder, who has granted medRxiv a license to display the preprint in perpetuity.

It is made available under a CC-BY-NC-ND 4.0 International license.

A) Peak viral concentration

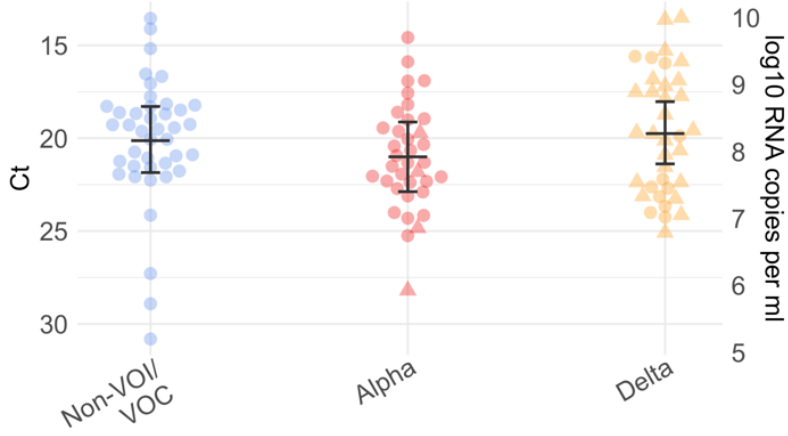

C) Clearance time

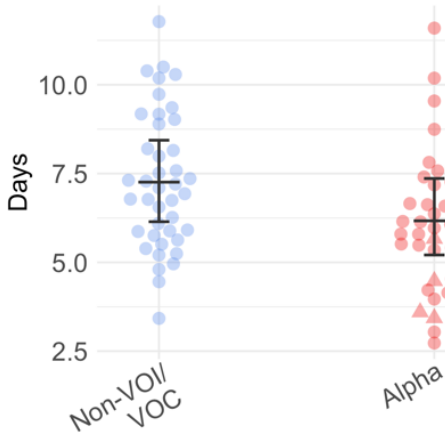

272

273

E) 15

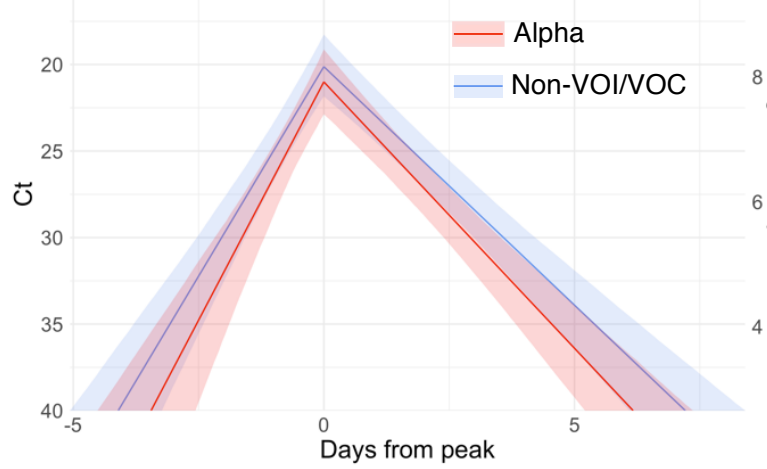

Days from peak

Unvaccinated
B) Proliferation time

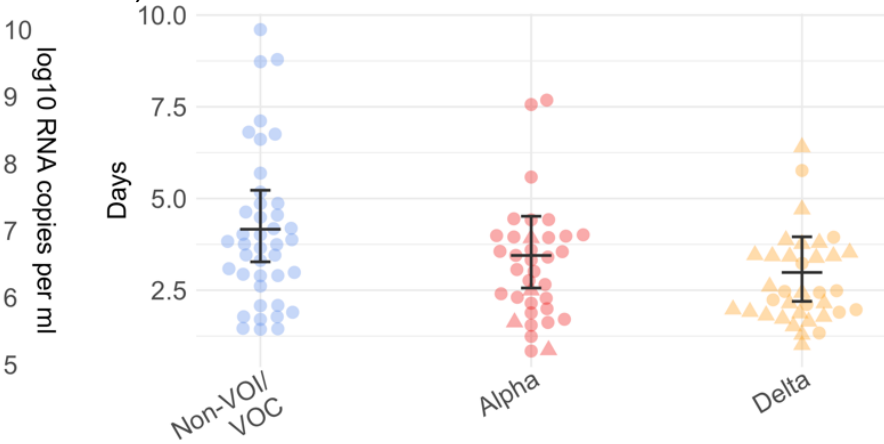

D) Acute infection duration

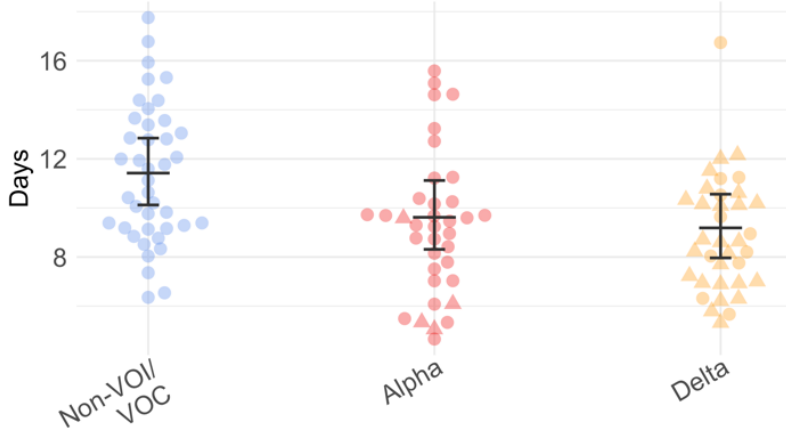

Vaccinated (breakthrough)

F) 15
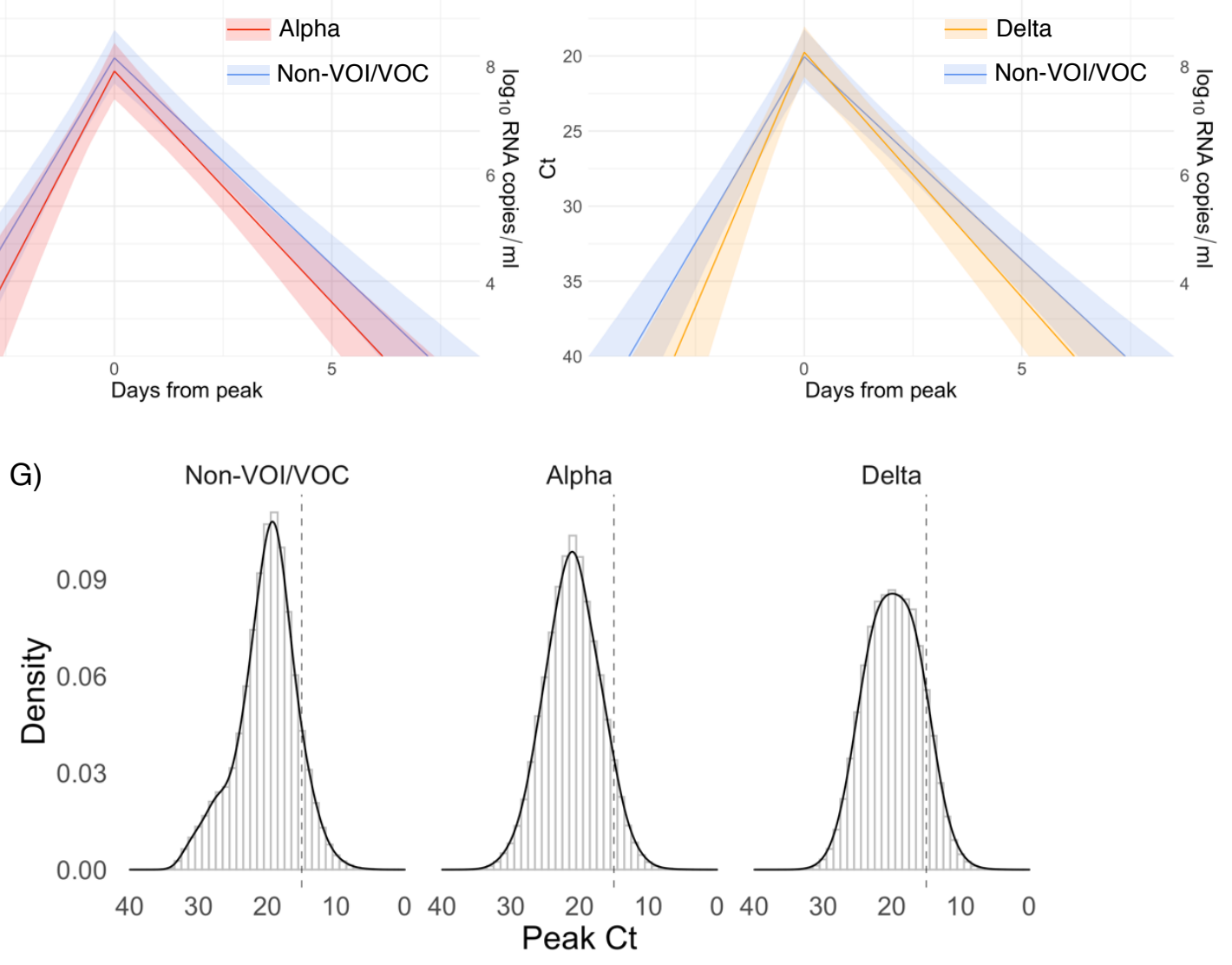
medRxiv preprint doi: https://doi.org/10.1101/2021.02.16.21251535; this version posted August 25, 2021. The copyright holder for this preprint (which was not certified by peer review) is the author/funder, who has granted medRxiv a license to display the preprint in perpetuity.

It is made available under a CC-BY-NC-ND 4.0 International license.

Figure 2. Estimated viral trajectory parameters for SARS-CoV-2 variants alpha and delta. Individual posterior means (points) with population means and $95 \%$ credible intervals (hatched lines) for (A) the peak viral concentration, (B) the proliferation duration, (C) the clearance duration, and (D) the total duration of acute infection for individuals infected with a non-VOI/NOC (light blue), alpha (red), or delta (orange). Circles denote unvaccinated individuals and triangles denote vaccinated individuals (breakthroughs). The points are jittered horizontally to avoid overlap. Panes $(E)-(F)$ depict the mean posterior viral trajectories for alpha $(E, r e d)$ and delta $(F$, orange) infections relative to non-VOI/VOC infections (light blue), as specified by the population means and credible intervals in (A)-(D). Solid lines in panes (E)-(F) depict the mean posterior viral trajectories and shaded regions represent $95 \%$ credible areas for the mean posterior trajectories. Histograms in pane $(\mathrm{G})$ depict the posterior distributions of peak $\mathrm{Ct}$ values aggregated across all individuals infected with a non-VOI/VOC, alpha, and delta. The dashed line marks $\mathrm{Ct}=15\left(9.6 \log _{10} \mathrm{RNA}\right.$ copies $/ \mathrm{ml}$ ) to facilitate comparison of the frequency of low peak Ct values/high peak viral concentrations across variants. 
medRxiv preprint doi: https://doi.org/10.1101/2021.02.16.21251535; this version posted August 25, 2021. The copyright holder for this preprint (which was not certified by peer review) is the author/funder, who has granted medRxiv a license to display the preprint in perpetuity.

It is made available under a CC-BY-NC-ND 4.0 International license .

A) Peak viral concentration
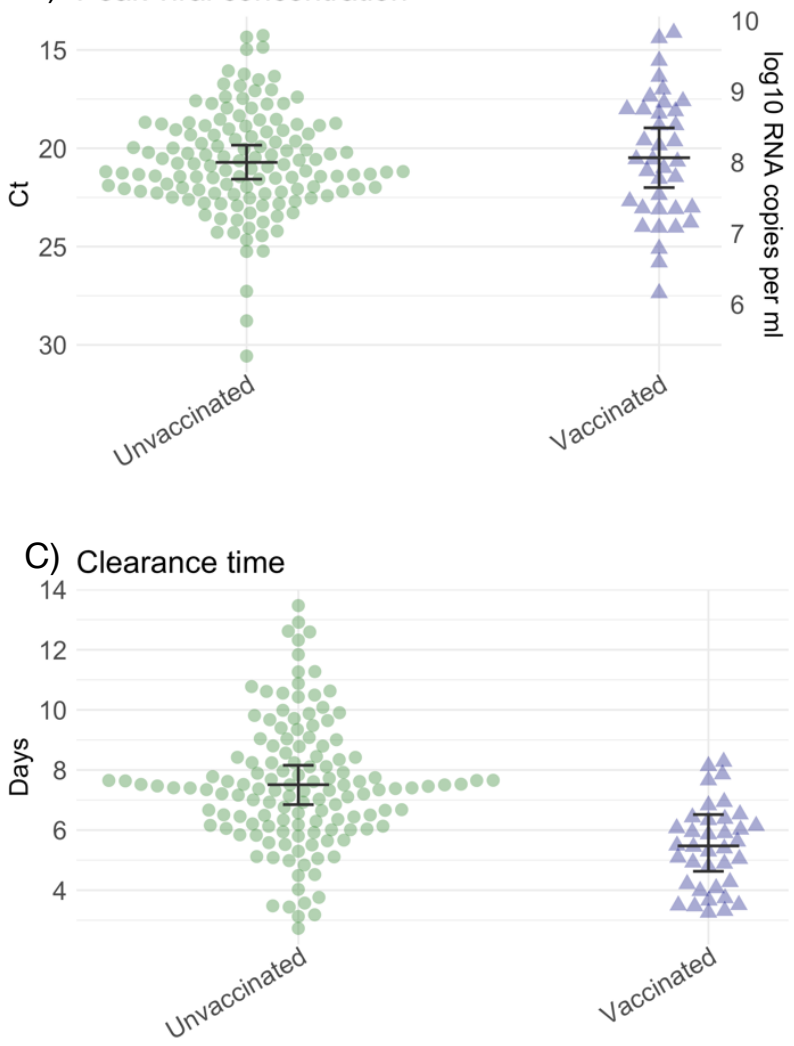

B) Proliferation time

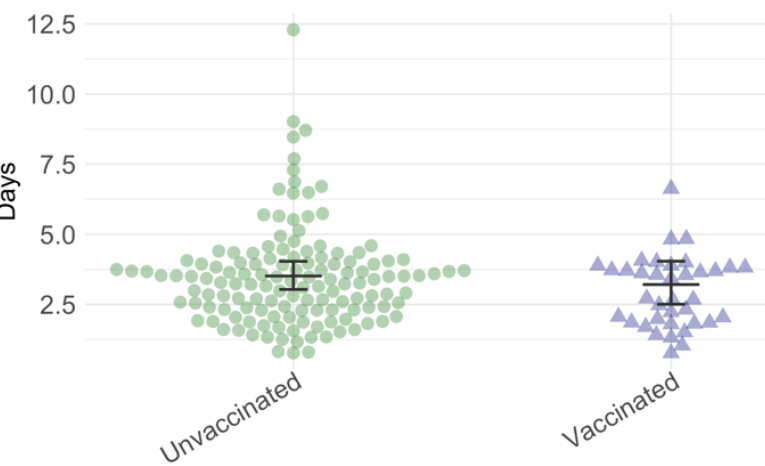

D) Acute infection duration

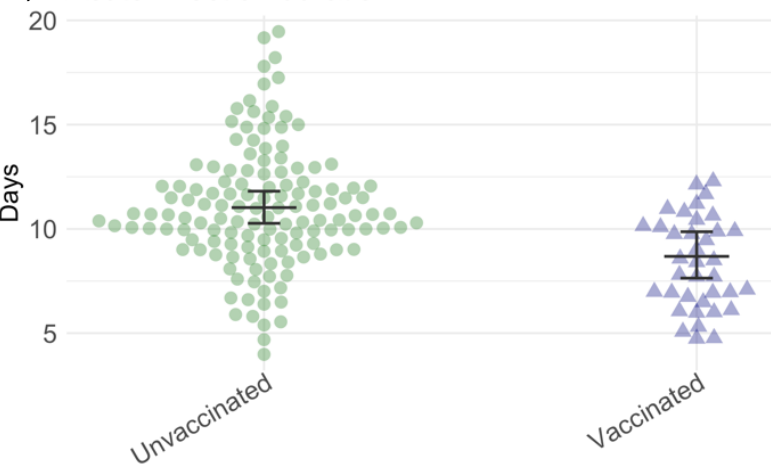

E) 15

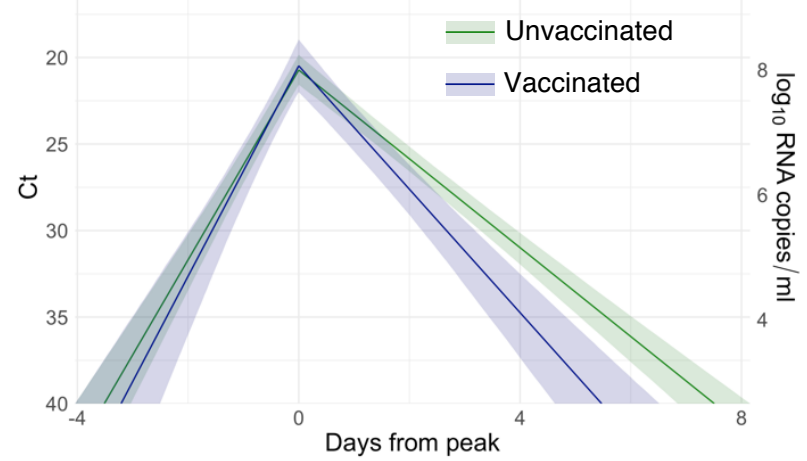

Figure 3. Estimated viral trajectory parameters for SARS-CoV-2 infections in unvaccinated and vaccinated individuals. Individual posterior means (points) with population means and $95 \%$ credible intervals (hatched lines) for (A) the peak viral concentration, (B) the proliferation duration, $(C)$ the clearance duration, and (D) the total duration of acute infection for unvaccinated individuals (green) and vaccinated individuals (dark blue). Circles denote unvaccinated individuals and triangles denote vaccinated individuals (breakthroughs). The points are jittered horizontally to avoid overlap. Pane (E) depicts the mean posterior viral trajectories for vaccinated individuals (green) relative to unvaccinated individuals (dark blue), as specified by the population means and credible intervals in (A)-(D). Solid lines in pane (E) depict the mean posterior viral trajectories and shaded regions represent $95 \%$ credible areas for the mean posterior trajectories. 
medRxiv preprint doi: https://doi.org/10.1101/2021.02.16.21251535; this version posted August 25, 2021. The copyright holder for this preprint (which was not certified by peer review) is the author/funder, who has granted medRxiv a license to display the preprint in perpetuity.

It is made available under a CC-BY-NC-ND 4.0 International license.

\section{References}

1. Centers for Disease Control and Prevention. COVID Data Tracker. Published 2021. Accessed May 20, 2021. https://covid.cdc.gov/covid-data-tracker/

2. Galloway SE, Paul P, MacCannell DR, Johansson MA, Brooks JT, MacNeil A, et al. Emergence of SARS-CoV-2 B.1.1.7 Lineage - United States, December 29, 2020-January 12, 2021. MMWR Morb Mortal Wkly Rep. 2021;70(3):95-99. doi:10.15585/mmwr.mm7003e2

3. Yi C, Sun X, Ye J, Ding L, Liu M, Yang Z, et al. Key residues of the receptor binding motif in the spike protein of SARS-CoV-2 that interact with ACE2 and neutralizing antibodies. Cell Mol Immunol. 2020;17(6):621-630. doi:10.1038/s41423-020-0458-z

4. Bailly B, Guilpain L, Bouiller K, Chirouze C, N'Debi M, Soulier A, et al. BNT162b2 Messenger RNA Vaccination Did Not Prevent an Outbreak of Severe Acute Respiratory Syndrome Coronavirus 2 Variant 501Y.V2 in an Elderly Nursing Home but Reduced Transmission and Disease Severity. Clin Infect Dis. Published online May 16, 2021. doi:10.1093/cid/ciab446

5. Brinkley-Rubinstein L, Peterson M, Martin R, Chan P, Berk J. Breakthrough SARS-CoV-2 Infections in Prison after Vaccination. N Engl J Med. Published online July 7 , 2021:NEJMc2108479. doi:10.1056/NEJMc2108479

6. Li B, Deng A, Li K, Hu Y, Li Z, Xiong Q, et al. Viral infection and transmission in a large, welltraced outbreak caused by the SARS-CoV-2 Delta variant. medRxiv. Published online 2021.

7. Ke R, Martinez PP, Smith RL, Gibson LL, Mirza A, Conte M, et al. Daily sampling of early SARSCoV-2 infection reveals substantial heterogeneity in infectiousness. medRxiv. Published online 2021. doi:https://www.medrxiv.org/content/10.1101/2021.07.12.21260208v1

8. Chia PY, Ong SWX, Chiew CJ, Ang LW, Chavatte J-M, Mak T-M, et al. Virological and serological kinetics of SARS-CoV-2 Delta variant vaccine-breakthrough infections: a multi-center cohort study. medRxiv. Published online 2021.

9. Brown CM, Vostok J, Johnson H, Burns M, Gharpure R, Sami S, et al. Outbreak of SARS-CoV-2 Infections, Including COVID-19 Vaccine Breakthrough Infections, Associated with Large Public Gatherings - Barnstable County, Massachusetts, July 2021. MMWR Morb Mortal Wkly Rep. 2021;70(31):1059-1062. doi:10.15585/mmwr.mm7031e2

10. Hay JA, Kennedy-Shaffer L, Kanjilal S, Lennon NJ, Gabriel SB, Lipsitch M, et al. Estimating epidemiologic dynamics from cross-sectional viral load distributions. Science (80- ). 2021;373(6552):eabh0635. doi:10.1126/science.abh0635

11. United States Food and Drug Administration. Emergency Use Authorization for TaqPath COVID19 Combo Kit.; 2020. https://www.fda.gov/media/136113/download

12. Loman N, Rowe W, Rambaut A. nCoV-2019 novel coronavirus bioinformatics protocol.

13. Illumina. Illumina COVIDSeq Test Instructions for Use.; 2021.

https://www.fda.gov/media/138776/download

14. Illumina. NextSeq 550 System Documentation. Published 2021. Accessed June 10, 2021. https://support.illumina.com/sequencing/sequencing_instruments/nextseq-550/documentation.html

15. BaseSpace Labs. DRAGEN COVID Lineage. Published online 2021.

16. Rambaut A, Holmes EC, O'Toole Á, Hill V, McCrone JT, Ruis C, et al. A dynamic nomenclature proposal for SARS-CoV-2 lineages to assist genomic epidemiology. Nat Microbiol. 2020;5(11):1403-1407. doi:10.1038/s41564-020-0770-5

17. Aksamentov I, Neher R. NextClade. Published 2021. Accessed June 10, 2021. https://clades.nextstrain.org/

18. Kissler SM, Fauver JR, Mack C, Olesen SW, Tai C, Shiue KY, et al. Viral dynamics of acute SARS-CoV-2 infection and applications to diagnostic and public health strategies. PLoS Biol. 2021;19(7):1-17. doi:10.1371/journal.pbio.3001333

19. Carpenter B, Gelman A, Hoffman MD, Lee D, Goodrich B, Betancourt M, et al. Stan : A Probabilistic Programming Language. J Stat Softw. 2017;76(1). doi:10.18637/jss.v076.i01

20. Kissler SM. Github Repository: CtTrajectories_AllVariants. Published 2021. Accessed June 14, 2021. https://github.com/gradlab/CtTrajectories_AllVariants

21. Gelman A, Carlin JB, Stern HS, Dunson DB, Vehtari A, Rubin DB. Bayesian Data Analysis. 3rd ed. 
medRxiv preprint doi: https://doi.org/10.1101/2021.02.16.21251535; this version posted August 25, 2021. The copyright holder for this preprint (which was not certified by peer review) is the author/funder, who has granted medRxiv a license to display the preprint in perpetuity.

CRC Press; 2013.

22. Davies NG, Abbott S, Barnard RC, Jarvis CI, Kucharski AJ, Munday JD, et al. Estimated transmissibility and impact of SARS-CoV-2 lineage B.1.1.7 in England. Science (80- ). 2021;372(6538):eabg3055. doi:10.1126/science.abg3055

23. Mack CD, Wasserman EB, Perrine CG, MacNeil A, Anderson DJ, Myers E, et al. Implementation and Evolution of Mitigation Measures, Testing, and Contact Tracing in the National Football League, August 9-November 21, 2020. MMWR Morb Mortal Wkly Rep. 2021;70(4):130-135. doi:10.15585/mmwr.mm7004e2

24. Fisman DN, Tuite AR. Progressive Increase in Virulence of Novel SARS-CoV-2 Variants in Ontario, Canada. medRxiv. Published online 2021.

25. Baden LR, El Sahly HM, Essink B, Kotloff K, Frey S, Novak R, et al. Efficacy and Safety of the mRNA-1273 SARS-CoV-2 Vaccine. N Engl J Med. 2021;384(5):403-416. doi:10.1056/NEJMoa2035389

26. Polack FP, Thomas SJ, Kitchin N, Absalon J, Gurtman A, Lockhart S, et al. Safety and Efficacy of the BNT162b2 mRNA Covid-19 Vaccine. N Engl J Med. 2020;383(27):2603-2615. doi:10.1056/NEJMoa2034577

27. Oliver SE, Gargano JW, Scobie H, Wallace M, Hadler SC, Leung J, et al. The Advisory Committee on Immunization Practices' Interim Recommendation for Use of Janssen COVID-19 Vaccine United States, February 2021. MMWR Morb Mortal Wkly Rep. 2021;70(9):329-332. doi:10.15585/mmwr.mm7009e4

28. Andrejko KL, Pry J, Myers JF, Jewell NP, Openshaw J, Watt J, et al. Prevention of COVID-19 by mRNA-based vaccines within the general population of California. medRxiv. Published online 2021.

29. Corchado-Garcia J, Puyraimond-Zemmour D, Hughes T, Cristea-Platon T, Lenehan P, Pawlowski C, et al. Real-world effectiveness of Ad26.COV2.S adenoviral vector vaccine for COVID-19. medRxiv. Published online 2021.

30. Pawlowski C, Lenehan P, Puranik A, Agarwal V, Venkatakrishnan A, Niesen MJM, et al. FDAauthorized COVID-19 vaccines are effective per real-world evidence synthesized across a multistate health system. medRxiv. Published online 2021.

31. Singanayagam A, Patel M, Charlett A, Lopez Bernal J, Saliba V, Ellis J, et al. Duration of infectiousness and correlation with RT-PCR cycle threshold values in cases of COVID-19, England, January to May 2020. Euro Surveill. 2020;25(32):1-5. doi:10.2807/15607917.ES.2020.25.32.2001483

32. Butler D, Mozsary C, Meydan C, Foox J, Rosiene J, Shaiber A, et al. Shotgun transcriptome, spatial omics, and isothermal profiling of SARS-CoV-2 infection reveals unique host responses, viral diversification, and drug interactions. Nat Commun. 2021;12(1):1660. doi:10.1038/s41467021-21361-7

33. Kudo E, Israelow B, Vogels CBF, Lu P, Wyllie AL, Tokuyama M, et al. Detection of SARS-CoV-2 RNA by multiplex RT-qPCR. Sugden B, ed. PLOS Biol. 2020;18(10):e3000867. doi:10.1371/journal.pbio.3000867

34. Vogels C, Fauver J, Ott IM, Grubaugh N. Generation of SARS-COV-2 RNA Transcript Standards for QRT-PCR Detection Assays.; 2020. doi:10.17504/protocols.io.bdv6i69e

35. Cleary B, Hay JA, Blumenstiel B, Gabriel S, Regev A, Mina MJ. Efficient prevalence estimation and infected sample identification with group testing for SARS-CoV-2. medRxiv. Published online 2020.

36. Tom MR, Mina MJ. To Interpret the SARS-CoV-2 Test, Consider the Cycle Threshold Value. Clin Infect Dis. 2020;02115(Xx):1-3. doi:10.1093/cid/ciaa619

37. R Development Core Team R. R: A Language and Environment for Statistical Computing. Team RDC, ed. R Found Stat Comput. 2011;1(2.11.1):409. doi:10.1007/978-3-540-74686-7

38. Kissler SM, Fauver JR, Mack C, Olesen SW, Tai C, Shiue KY, et al. Viral dynamics of acute SARS-CoV-2 infection and applications to diagnostic and public health strategies. Riley S, ed. PLOS Biol. 2021;19(7):e3001333. doi:10.1371/journal.pbio.3001333 
medRxiv preprint doi: https://doi.org/10.1101/2021.02.16.21251535; this version posted August 25, 2021. The copyright holder for this preprint (which was not certified by peer review) is the author/funder, who has granted medRxiv a license to display the preprint in perpetuity.

It is made available under a CC-BY-NC-ND 4.0 International license .

\section{Supplementary Appendix.}

Converting Ct values to viral genome equivalents. To convert $\mathrm{Ct}$ values to viral genome equivalents, we first converted the Roche cobas target $1 \mathrm{Ct}$ values to equivalent $\mathrm{Ct}$ values on a multiplexed version of the RT-qPCR assay from the US Centers for Disease Control and Prevention. ${ }^{33}$ We did this following our previously described methods. ${ }^{18}$ Briefly, we adjusted the Ct values using the best-fit linear regression between previously collected Roche cobas target 1 $\mathrm{Ct}$ values and $\mathrm{CDC}$ multiplex $\mathrm{Ct}$ values using the following regression equation:

$$
y_{i}=\beta_{0}+\beta_{1} x_{i}+\epsilon_{i}
$$

Here, $y_{i}$ denotes the $i^{\text {th }} \mathrm{Ct}$ value from the CDC multiplex assay, $x_{i}$ denotes the $i^{\text {th }} \mathrm{Ct}$ value from the Roche cobas target 1 test, and $\varepsilon_{i}$ is an error term with mean 0 and constant variance across all samples. The coefficient values are $\beta_{0}=-6.25$ and $\beta_{1}=1.34$.

Ct values were fitted to a standard curve to convert Ct value data to RNA copies. Synthetic T7 RNA transcripts corresponding to a 1,363 b.p. segment of the SARS-CoV-2 nucleocapsid gene were serially diluted from $10^{6}-10^{\circ} \mathrm{RNA}$ copies/ $\mu \mathrm{l}$ in duplicate to generate a standard curve ${ }^{34}$ (Supplementary Table 2). The average Ct value for each dilution was used to calculate the slope (-3.60971) and intercept (40.93733) of the linear regression of Ct on $\log _{10}$ transformed standard RNA concentration, and Ct values from subsequent RT-qPCR runs were converted to RNA copies using the following equation:

$$
\log _{10}([\mathrm{RNA}])=(C t-40.93733) /(-3.60971)+\log _{10}(250)
$$

Here, [RNA] represents the RNA copies $/ \mathrm{ml}$. The $\log _{10}(250)$ term accounts for the extraction (300 $\mu l)$ and elution $(75 \mu l)$ volumes associated with processing the clinical samples as well as the $1,000 \mu \mathrm{l} / \mathrm{ml}$ unit conversion.

Model fitting.

For the statistical analysis, we removed any sequences of 3 or more consecutive negative tests $(\mathrm{Ct}=40)$ to avoid overfitting to these trivial values. Following our previously described methods, ${ }^{18}$ we assumed that the viral concentration trajectories consisted of a proliferation phase, with 
medRxiv preprint doi: https://doi.org/10.1101/2021.02.16.21251535; this version posted August 25, 2021. The copyright holder for this preprint (which was not certified by peer review) is the author/funder, who has granted medRxiv a license to display the preprint in perpetuity.

It is made available under a CC-BY-NC-ND 4.0 International license .

exponential growth in viral RNA concentration, followed by a clearance phase characterized by exponential decay in viral RNA concentration. ${ }^{35}$ Since Ct values are roughly proportional to the negative logarithm of viral concentration ${ }^{36}$, this corresponds to a linear decrease in Ct followed by a linear increase. We therefore constructed a piecewise-linear regression model to estimate the peak $\mathrm{Ct}$ value, the time from infection onset to peak (i.e. the duration of the proliferation stage), and the time from peak to infection resolution (i.e. the duration of the clearance stage). The trajectory may be represented by the equation

$$
E[C t(t)]= \begin{cases}\text { l.o.d. } & t \leq t_{o} \\ \text { l.o.d. }-\frac{\delta}{t_{p}-t_{o}}\left(t-t_{o}\right) & t_{o}<t \leq t_{p} \\ \text { l.o.d. }-\delta+\frac{\delta}{t_{r}-t_{p}}\left(t-t_{p}\right) & t_{p}<t \leq t_{r} \\ \text { l.o.d. } & t>t_{r}\end{cases}
$$

Here, $\mathrm{E}[\mathrm{Ct}(\mathrm{t})]$ represents the expected value of the $\mathrm{Ct}$ at time $t$, "I.o.d" represents the RT-qPCR limit of detection, $\delta$ is the absolute difference in Ct between the limit of detection and the peak (lowest) $\mathrm{Ct}$, and $t_{o}, t_{p}$, and $t_{r}$ are the onset, peak, and recovery times, respectively.

Before fitting, we re-parametrized the model using the following definitions:

- $\Delta C t(t)=$ l.o.d. $-C t(t)$ is the difference between the limit of detection and the observed $\mathrm{Ct}$ value at time $t$.

- $\omega_{p}=t_{p}-t_{o}$ is the duration of the proliferation stage.

- $\omega_{r}=t_{r}-t_{p}$ is the duration of the clearance stage.

We constrained $0.25 \leq \omega_{p} \leq 14$ days and $2 \leq \omega_{r} \leq 30$ days to prevent inferring unrealistically small or large values for these parameters for trajectories that were missing data prior to the peak and after the peak, respectively. We also constrained $0 \leq \delta \leq 40$ as Ct values can only take values between 0 and the limit of detection (40).

We next assumed that the observed $\Delta C t(t)$ could be described the following mixture model:

$$
\Delta C t(t) \sim \lambda \operatorname{Normal}(E[\Delta C t(t)], \sigma(t))+(1-\lambda) \operatorname{Exponential}(\log (10))]_{0}^{1 . o . d}
$$


medRxiv preprint doi: https://doi.org/10.1101/2021.02.16.21251535; this version posted August 25, 2021. The copyright holder for this preprint (which was not certified by peer review) is the author/funder, who has granted medRxiv a license to display the preprint in perpetuity.

It is made available under a CC-BY-NC-ND 4.0 International license .

where $E[\Delta C t(t)]=$ l.o.d. $-E[C t(t)]$ and $\lambda$ is the sensitivity of the q-PCR test, which we fixed at 0.99. The bracket term on the right-hand side of the equation denotes that the distribution was truncated to ensure $\mathrm{Ct}$ values between 0 and the limit of detection. This model captures the scenario where most observed $\mathrm{Ct}$ values are normally distributed around the expected trajectory with standard deviation $\sigma(t)$, yet there is a small $(1 \%)$ probability of an exponentially distributed false negative near the limit of detection. The $\log (10)$ rate of the exponential distribution was chosen so that $90 \%$ of the mass of the distribution sat below $1 \mathrm{Ct}$ unit and $99 \%$ of the distribution sat below $2 \mathrm{Ct}$ units, ensuring that the distribution captures values distributed at or near the limit of detection. We did not estimate values for $\lambda$ or the exponential rate because they were not of interest in this study; we simply needed to include them to account for some small probability mass that persisted near the limit of detection to allow for the possibility of false negatives.

We used a hierarchical structure to describe the distributions of $\omega_{p}, \omega_{r}$, and $\delta$ for each person based on their respective population means $\mu_{\omega p}, \mu_{\omega r}$, and $\mu_{\delta}$ and population standard deviations $\sigma_{\omega p}, \sigma_{\omega r}$, and $\sigma_{\delta}$ such that

$\omega_{p} \sim \operatorname{Normal}\left(\mu_{\omega p}, \sigma_{\omega p}\right)$

$\omega_{r} \sim \operatorname{Normal}\left(\mu_{\omega r}, \sigma_{\omega r}\right)$

$\delta \sim \operatorname{Normal}\left(\mu_{\delta}, \sigma_{\delta}\right)$

We inferred population means $(\mu$.) separately for individuals infected with alpha, delta, and nonVOI/VOCs, as well as for unvaccinated and vaccinated individuals in a separate analysis. We used a Hamiltonian Monte Carlo fitting procedure implemented in Stan (version 2.24) ${ }^{19}$ and R (version 3.6.2) ${ }^{37}$ to estimate the individual-level parameters $\omega_{p}, \omega_{r}, \delta$, and $t_{p}$ as well as the population-level parameters $\sigma^{*}, \mu_{\omega p}, \mu_{\omega r}, \mu_{\bar{\delta}}, \sigma_{\omega p}, \sigma_{\omega r}$, and $\sigma_{\delta}$. We used the following priors:

Hyperparameters:

$\sigma^{*} \sim \operatorname{Cauchy}(0,5)[0, \infty]$

$\mu_{\omega p} \sim \operatorname{Normal}(2.7,14 / 6)[0.25,14]$

$\mu_{\omega r} \sim \operatorname{Normal}(7.4,30 / 6)[2,30]$ 
$\mu_{\delta} \sim \operatorname{Normal}(20,40 / 6)[0,40]$

$$
\begin{aligned}
& \sigma_{\omega p} \sim \operatorname{Cauchy}(0,14 / \tan (\pi(0.95-0.5)))[0, \infty] \\
& \sigma_{\omega r} \sim \operatorname{Cauchy}(0,30 / \tan (\pi(0.95-0.5)))[0, \infty] \\
& \sigma_{\delta} \sim \operatorname{Cauchy}(0,40 / \tan (\pi(0.95-0.5)))[0, \infty]
\end{aligned}
$$

Individual-level parameters:

$\omega_{p} \sim \operatorname{Normal}\left(\mu_{\omega p}, \sigma_{\omega p}\right)[0.25,14]$

$\omega_{r} \sim \operatorname{Normal}\left(\mu_{\omega r}, \sigma_{\omega r}\right)[2,30]$

$\delta \sim \operatorname{Normal}\left(\mu_{\delta}, \sigma_{\delta}\right)[0,40]$

$t_{p} \sim \operatorname{Normal}(0,2)$

The values in square brackets denote truncation bounds for the distributions. We chose a vague half-Cauchy prior with scale 5 for the observation variance $\sigma^{*}$. The priors for the population mean values $(\mu$.$) are normally distributed priors spanning the range of allowable values for that$ parameter; this prior is vague but expresses a mild preference for values near the posterior estimates obtained from a previous analysis. ${ }^{38}$ The priors for the population standard deviations $(\sigma$.$) are half Cauchy-distributed with scale chosen so that 90 \%$ of the distribution sits below the maximum value for that parameter; this prior is vague but expresses a mild preference for standard deviations close to 0 .

We ran four MCMC chains for 2,000 iterations each with a target average proposal acceptance probability of 0.8 . The first half of each chain was discarded as the warm-up. The Gelman R-hat statistic was less than 1.1 for all parameters. This indicates good overall mixing of the chains. There were no divergent iterations, indicating good exploration of the parameter space. The posterior distributions for $\mu_{\delta}, \mu_{\omega p}$, and $\mu_{\omega r}$, were estimated separately for individuals infected with alpha, delta, and non-VOI/VOCs as well as for vaccinated and unvaccinated individuals. These are depicted in Figure 1 (main text). Draws from the individual posterior viral trajectory distributions are depicted in Supplementary Figures 1-11. The mean posterior viral trajectories for each person are depicted in Supplementary Figure 12.

Assessing sensitivity to different priors. 
medRxiv preprint doi: https://doi.org/10.1101/2021.02.16.21251535; this version posted August 25, 2021. The copyright holder for this preprint (which was not certified by peer review) is the author/funder, who has granted medRxiv a license to display the preprint in perpetuity. It is made available under a CC-BY-NC-ND 4.0 International license.

540 To ensure that our findings were not overly influenced by the prior distributions, we re-fit the model

541 using two different sets of priors. The first "vague" set used posterior population means for $\mu_{\omega p}$,

$542 \mu_{\omega r}$, and $\mu_{\delta}$ chosen to lie near the center of the allowable range for those parameters. These priors

543 were defined by

544

$545 \mu_{\omega p} \sim \operatorname{Normal}(14 / 2,14 / 6)[0.25,14]$

$546 \mu_{\omega r} \sim \operatorname{Normal}(30 / 2,30 / 6)[2,30]$

$547 \mu_{\delta} \sim \operatorname{Normal}(40 / 2,40 / 6)[0,40]$

The second set used unrealistically low prior means for $\mu_{\omega p}, \mu_{\omega r}$, and $\mu_{\delta}$ to check model robustness to highly biased prior distributions. These priors were defined by

$553 \quad \mu_{\omega r} \sim \operatorname{Normal}(0,30 / 6)[2,30]$

$554 \quad \mu_{\delta} \sim \operatorname{Normal}(20,40 / 6)[0,40]$.

Note that we updated the prior means but kept the prior variances at their original wide values to avoid encoding over-confidence in the priors into the model. The posterior population means for these new sets of priors are depicted in Supplementary Figures 13-14 (compare to Figures 23). Overall, the findings were consistent across choices of prior. 
medRxiv preprint doi: https://doi.org/10.1101/2021.02.16.21251535; this version posted August 25, 2021. The copyright holder for this preprint (which was not certified by peer review) is the author/funder, who has granted medRxiv a license to display the preprint in perpetuity.

\begin{tabular}{llllll} 
& Minimum Ct & $\begin{array}{l}\text { Maximum viral } \\
\text { concentration } \\
\left(\log _{10} \text { RNA copies/ml) }\right.\end{array}$ & $\begin{array}{l}\text { Proliferation } \\
\text { duration (days) }\end{array}$ & $\begin{array}{l}\text { Clearance } \\
\text { duration (days) }\end{array}$ & $\begin{array}{l}\text { Acute infection } \\
\text { duration (days) }\end{array}$ \\
\hline Non-VOI/VOC & $20.1[18.3,21.7]$ & $8.2[7.7,11.6]$ & $4.2[3.3,5.2]$ & $7.3[6.1,8.4]$ & $11.4[10.1,12.8]$ \\
Alpha & $21.0[19.1,20.9]$ & $7.9[8.0,11.5]$ & $3.4[2.6,4.5]$ & $6.2[5.2,7.4]$ & $9.6[8.3,11.1]$ \\
Delta & $19.8[18.0,22.0]$ & $8.3[7.7,11.6]$ & $3.0[2.2,4.0]$ & $6.2[5.2,7.4]$ & $9.2[8.0,10.6]$ \\
Unvaccinated & $20.7[19.8,20.2]$ & $8.0[8.2,11.5]$ & $3.5[3.0,4.0]$ & $7.5[6.8,8.2]$ & $11.0[10.3,11.8]$ \\
Vaccinated & $20.5[19.0,21.0]$ & $8.1[7.9,11.5]$ & $3.2[2.5,4.0]$ & $5.5[4.6,6.5]$ & $8.7[7.6,9.9]$
\end{tabular}

562

563 Supplementary Table 1. Posterior population viral trajectory parameters for SARS-CoV-2 infections

564 by variant and vaccination status. Reported values represent the posterior mean and $95 \%$ credible

565 intervals (brackets) for each parameter. 
medRxiv preprint doi: https://doi.org/10.1101/2021.02.16.21251535; this version posted August 25, 2021. The copyright holder for this preprint (which was not certified by peer review) is the author/funder, who has granted medRxiv a license to display the preprint in perpetuity.

It is made available under a CC-BY-NC-ND 4.0 International license.

\begin{tabular}{|c|c|c|c|}
\hline $\begin{array}{l}\text { Standard } \\
\text { (copies/ul) }\end{array}$ & Replicate 1 (Ct) & Replicate 2 (Ct) & Average Ct \\
\hline $10^{6}$ & 19.3 & 19.7 & 19.5 \\
\hline $10^{5}$ & 23.0 & 21.2 & 22.1 \\
\hline $10^{4}$ & 26.9 & 26.7 & 26.8 \\
\hline $10^{3}$ & 30.6 & 30.4 & 30.5 \\
\hline $10^{2}$ & 34.0 & 34.0 & 34.0 \\
\hline 101 & 37.2 & 36.6 & 36.9 \\
\hline $10^{\circ}$ & $\mathrm{N} / \mathrm{A}$ & 39.9 & 39.9 \\
\hline
\end{tabular}

Supplementary Table 2. Standard curve relationship between virus RNA copies and Ct values. Synthetic T7 RNA transcripts corresponding to a 1,363 base pair segment of the SARS-CoV-2 nucleocapsid gene were serially diluted from $10^{6}-10^{\circ}$ and evaluated in duplicate with RT-qPCR. The best-fit linear regression of the average $\mathrm{Ct}$ on the log10-transformed standard values had slope -3.60971 and intercept $40.93733\left(R^{2}=0.99\right)$. 
medRxiv preprint doi: https://doi.org/10.1101/2021.02.16.21251535; this version posted August 25, 2021. The copyright holder for this preprint (which was not certified by peer review) is the author/funder, who has granted medRxiv a license to display the preprint in perpetuity.
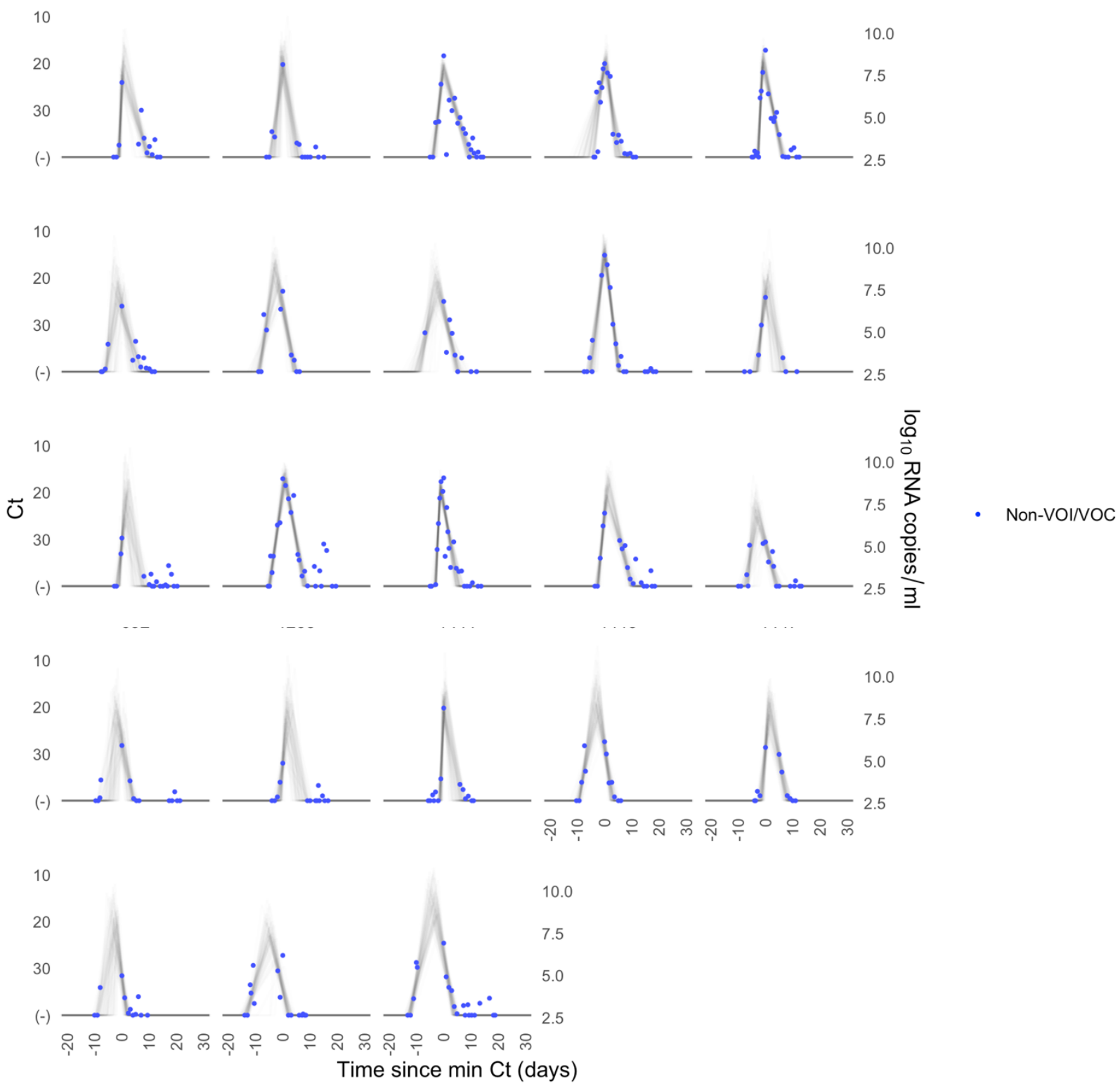

Supplementary Figure 1. Ct values and estimated trajectories for non-VOI/VOC SARS-CoV-2 infections (1/3). Each pane depicts the recorded Ct values (points) and derived log-10 genome equivalents per $\mathrm{ml}(\log (\mathrm{ge} / \mathrm{ml}))$ for a single person during the study period. Points along the horizontal axis represent negative tests. Time is indexed in days since the minimum recorded $\mathrm{Ct}$ value (maximum viral concentration). Lines depict 100 draws from the posterior distribution for each person's viral trajectory. Shaded boxes denote breakthrough infections. 
medRxiv preprint doi: https://doi.org/10.1101/2021.02.16.21251535; this version posted August 25, 2021. The copyright holder for this preprint (which was not certified by peer review) is the author/funder, who has granted medRxiv a license to display the preprint in perpetuity.
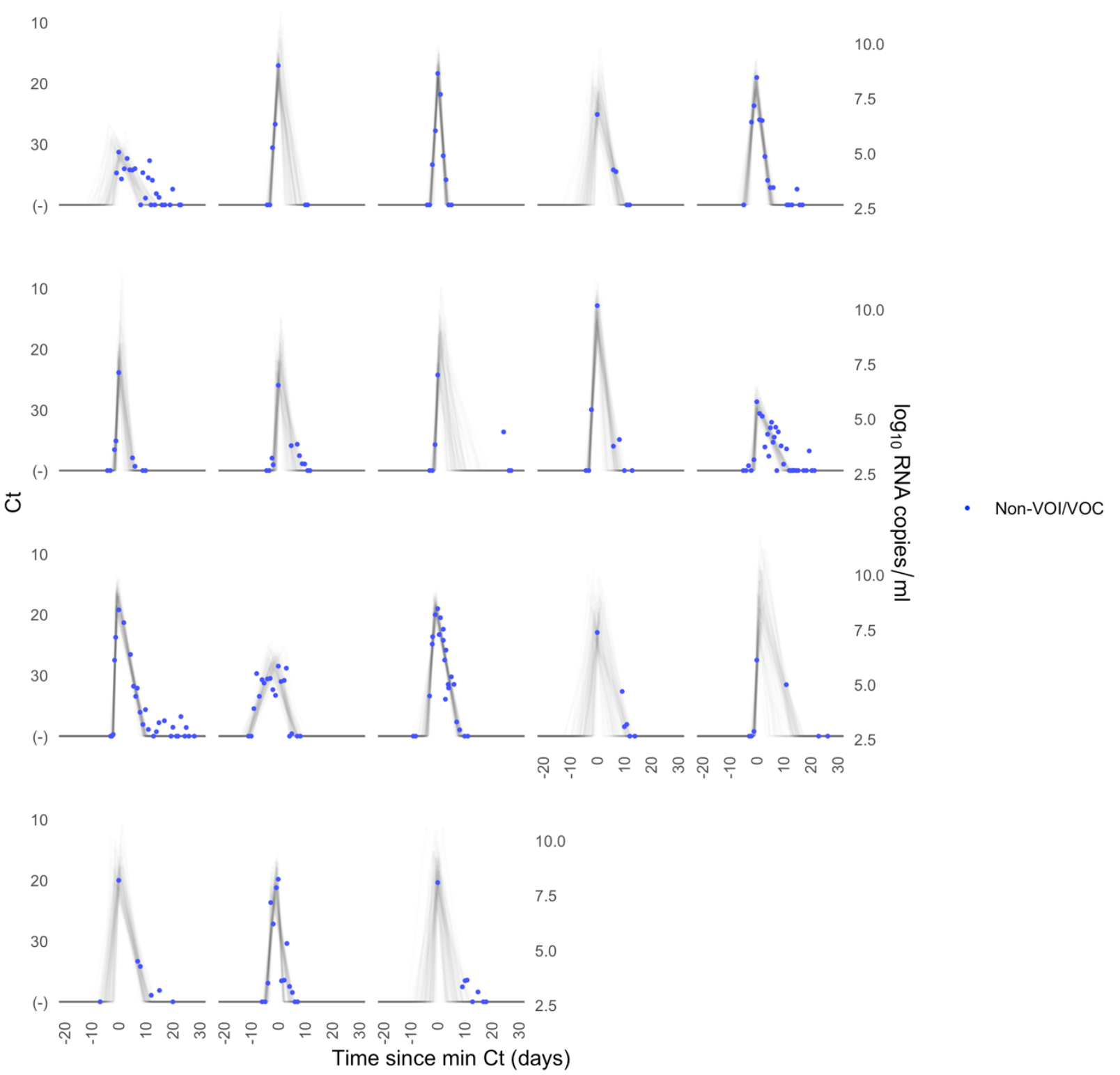

Supplementary Figure 2. Ct values and estimated trajectories for non-VOI/VOC SARS-CoV-2 infections (2/3). Each pane depicts the recorded $C t$ values (points) and derived log-10 genome equivalents per $\mathrm{ml}(\log (\mathrm{ge} / \mathrm{ml}))$ for a single person during the study period. Points along the horizontal axis represent negative tests. Time is indexed in days since the minimum recorded $\mathrm{Ct}$ value (maximum viral concentration). Lines depict 100 draws from the posterior distribution for each person's viral trajectory. Shaded boxes denote breakthrough infections. 
medRxiv preprint doi: https://doi.org/10.1101/2021.02.16.21251535; this version posted August 25, 2021. The copyright holder for this preprint (which was not certified by peer review) is the author/funder, who has granted medRxiv a license to display the preprint in perpetuity.

It is made available under a CC-BY-NC-ND 4.0 International license .
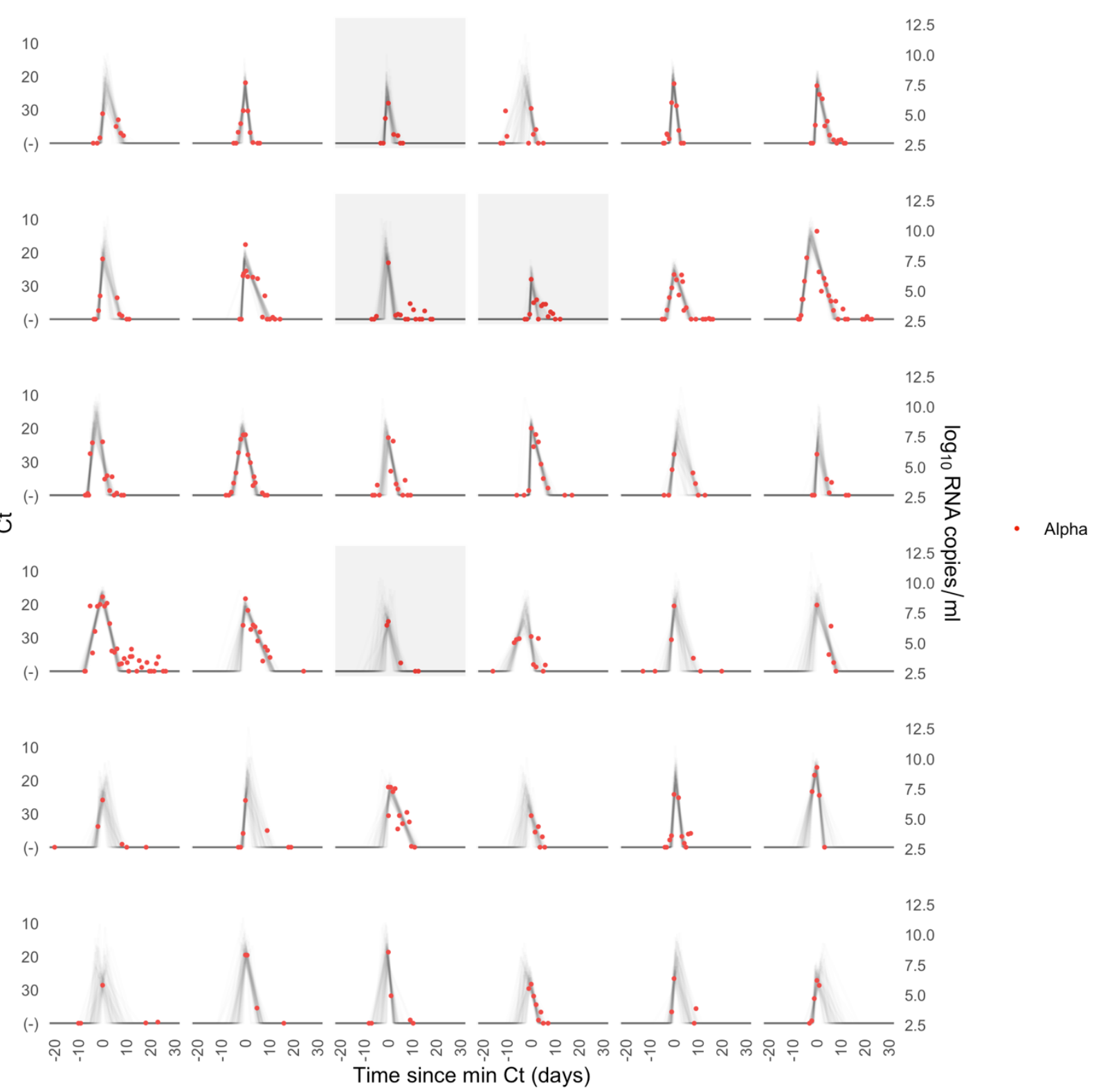

Supplementary Figure 3. Ct values and estimated trajectories for alpha SARS-CoV-2 infections. Each pane depicts the recorded Ct values (points) and derived log-10 genome equivalents per ml $(\log (\mathrm{ge} / \mathrm{ml}))$ for a single person during the study period. Points along the horizontal axis represent negative tests. Time is indexed in days since the minimum recorded $\mathrm{Ct}$ value (maximum viral concentration). Lines depict 100 draws from the posterior distribution for each person's viral trajectory. Shaded boxes denote breakthrough infections. 
medRxiv preprint doi: https://doi.org/10.1101/2021.02.16.21251535; this version posted August 25, 2021. The copyright holder for this preprint (which was not certified by peer review) is the author/funder, who has granted medRxiv a license to display the preprint in perpetuity.

It is made available under a CC-BY-NC-ND 4.0 International license.

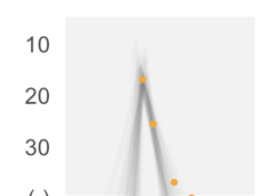

$(-)$
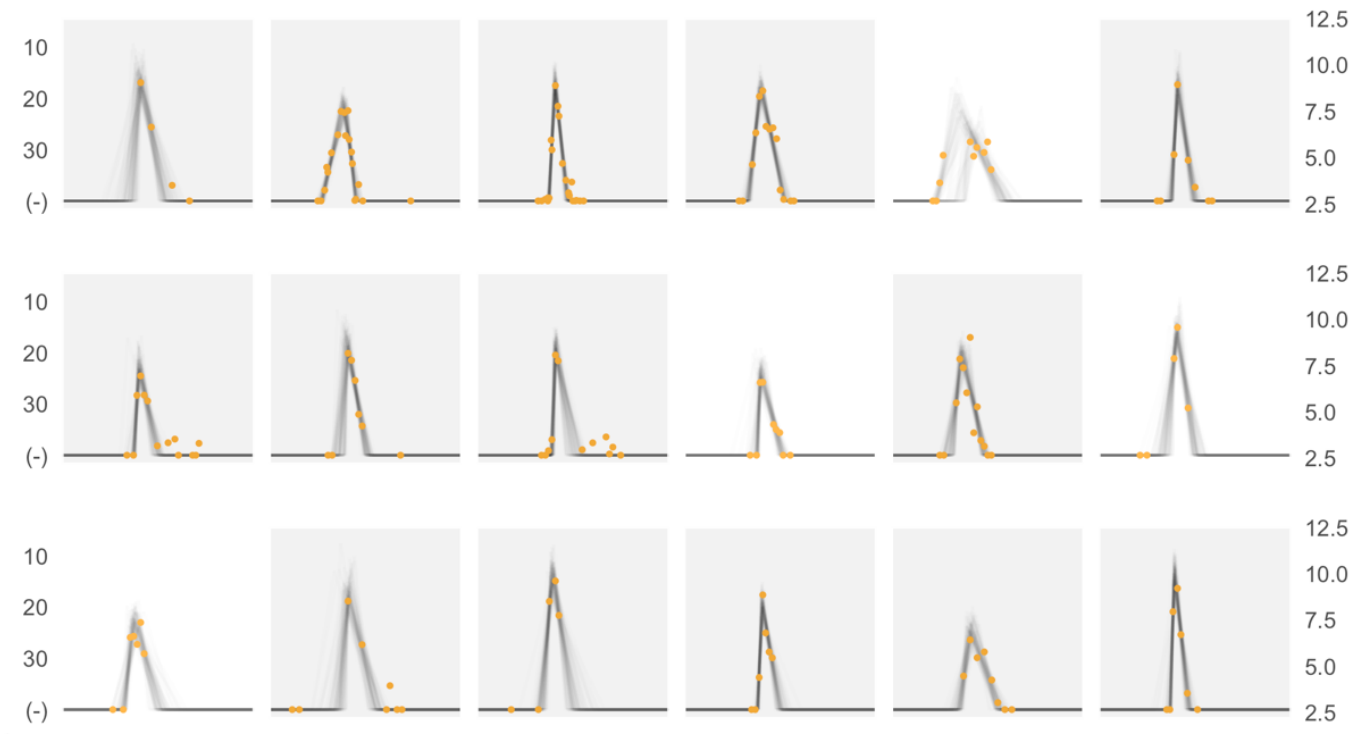

¿
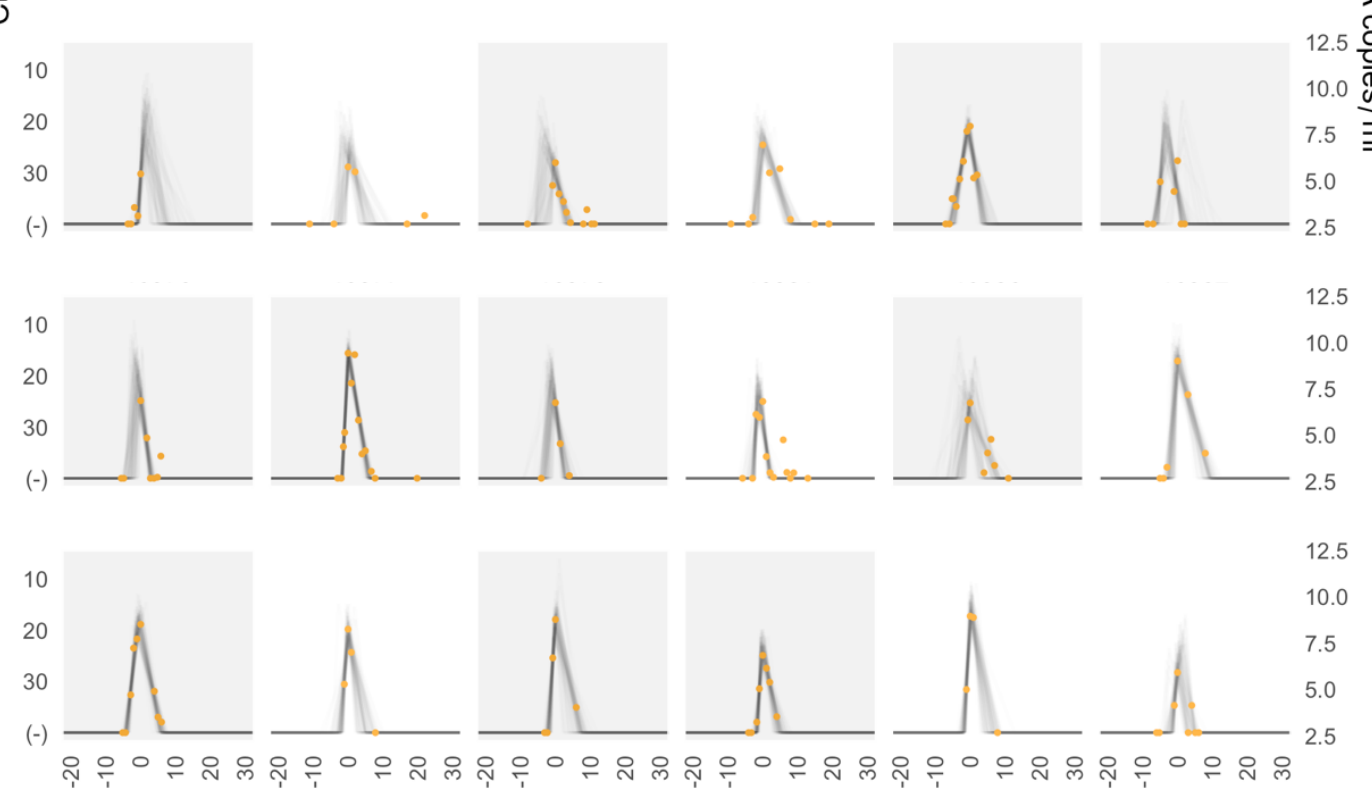

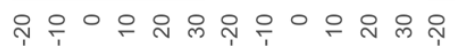
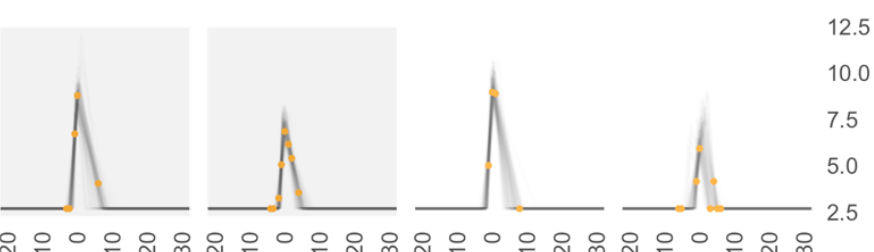

Time since min Ct (days)

Supplementary Figure 4. Ct values and estimated trajectories for delta SARS-CoV-2 infections. Each pane depicts the recorded Ct values (points) and derived log-10 genome equivalents per $\mathrm{ml}(\log (\mathrm{ge} / \mathrm{ml})$ ) for a single person during the study period. Points along the horizontal axis represent negative tests. Time is indexed in days since the minimum recorded Ct value (maximum viral concentration). Lines depict 100 draws from the posterior distribution for each person's viral trajectory. Shaded boxes denote breakthrough infections. 

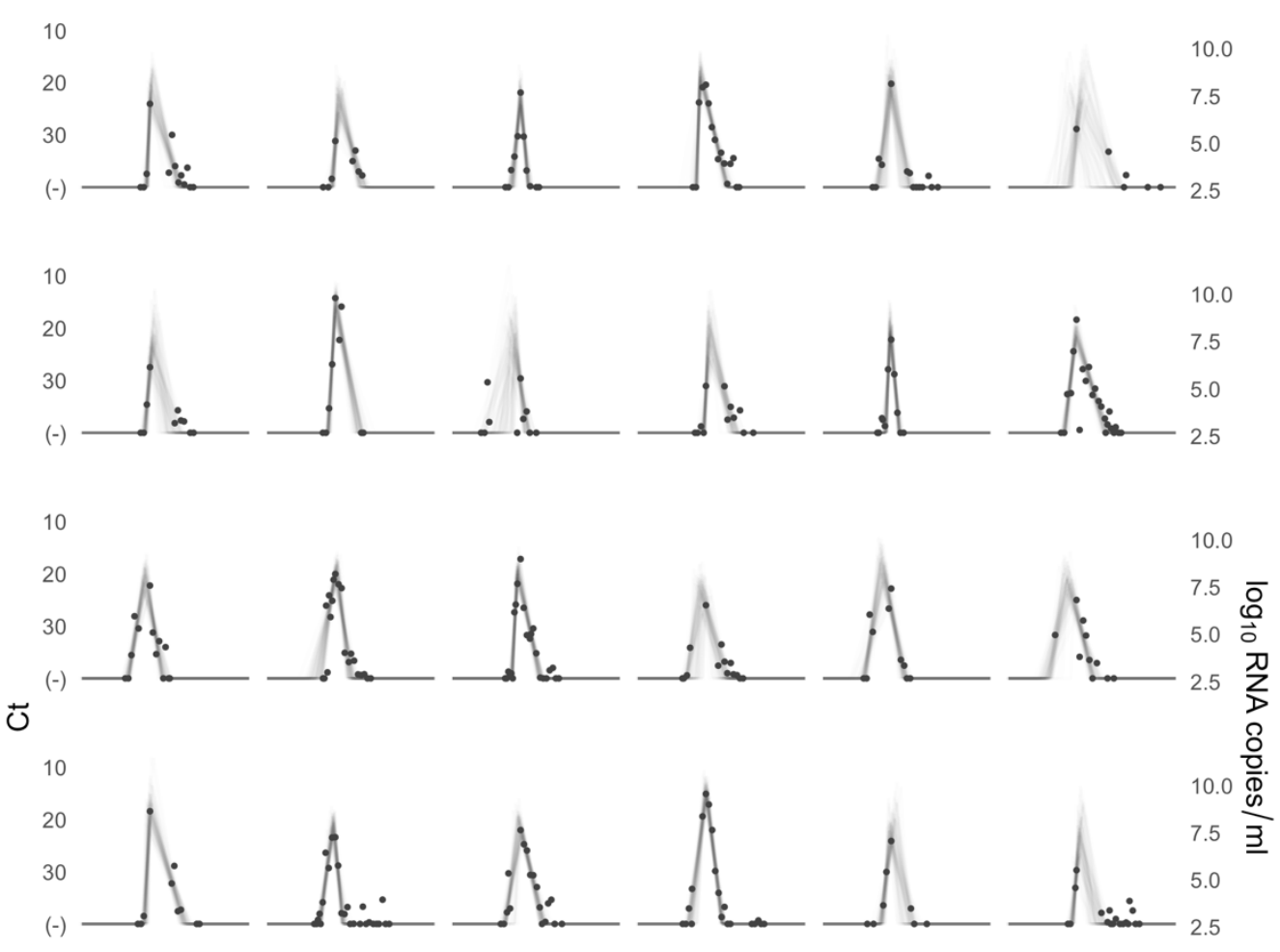

- Unvaccinated
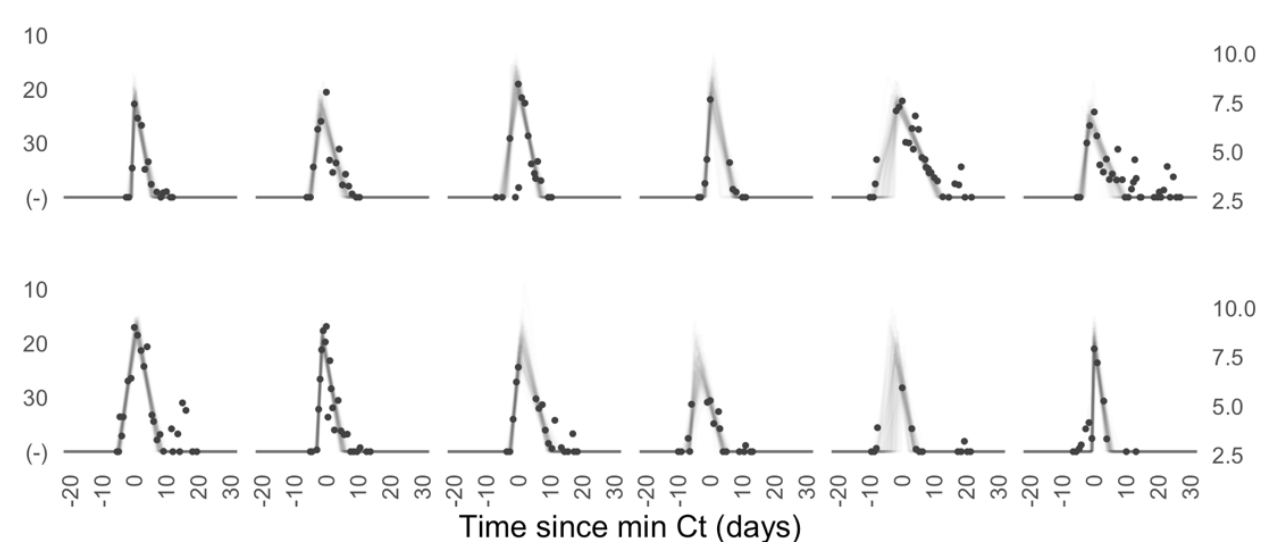

Supplementary Figure 5. Ct values and estimated trajectories for SARS-CoV-2 infections in unvaccinated individuals (1/4). Each pane depicts the recorded Ct values (points) and derived log-10 genome equivalents per $\mathrm{ml}(\log (\mathrm{ge} / \mathrm{ml}))$ for a single person during the study period. Points along the horizontal axis represent negative tests. Time is indexed in days since the minimum recorded $\mathrm{Ct}$ value (maximum viral concentration). Lines depict 100 draws from the posterior distribution for each person's viral trajectory. 
medRxiv preprint doi: https://doi.org/10.1101/2021.02.16.21251535; this version posted August 25, 2021. The copyright holder for this preprint (which was not certified by peer review) is the author/funder, who has granted medRxiv a license to display the preprint in perpetuity.
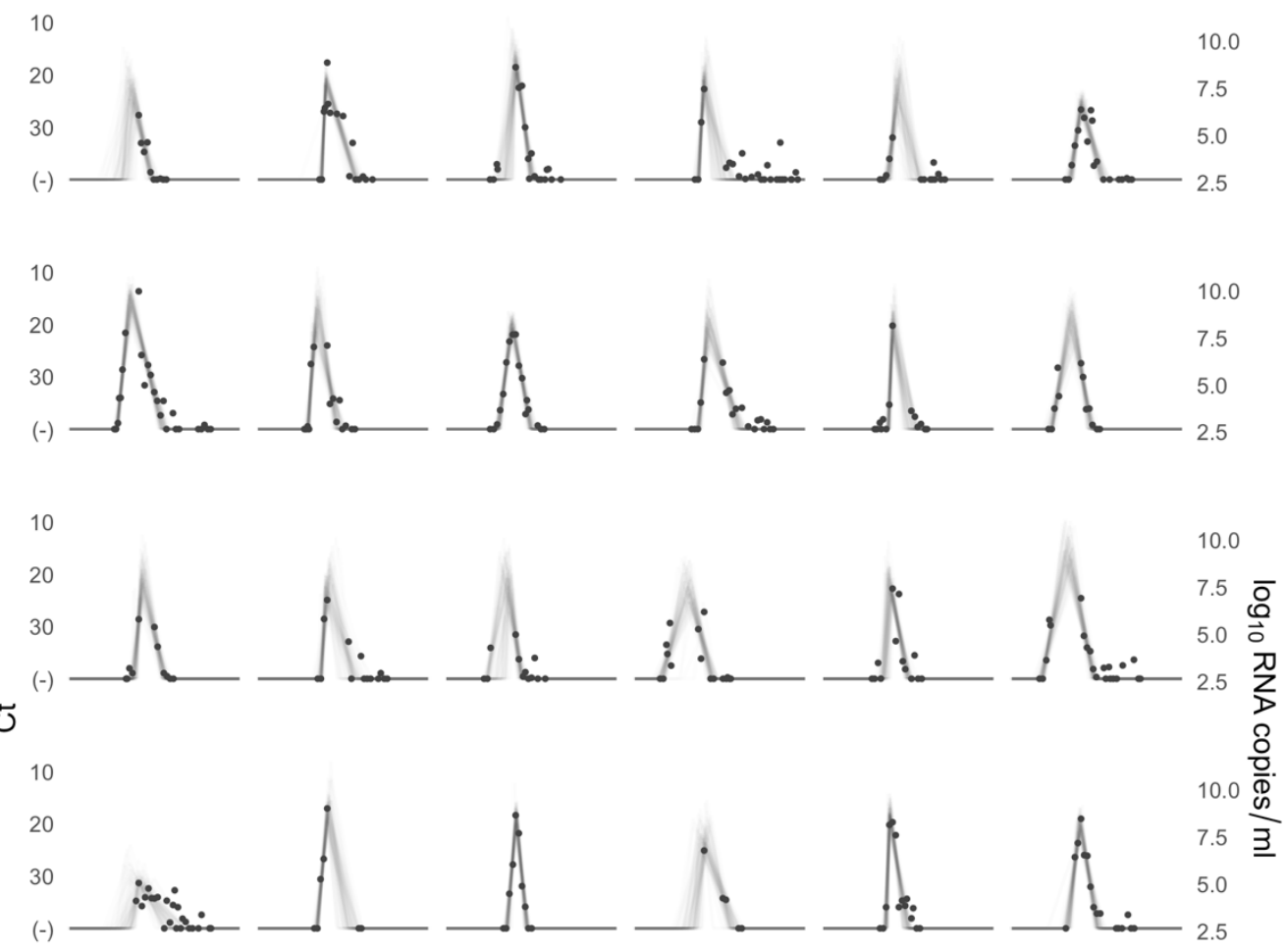

- Unvaccinated

Supplementary Figure 6. Ct values and estimated trajectories for SARS-CoV-2 infections in unvaccinated individuals (2/4). Each pane depicts the recorded Ct values (points) and derived log-10 genome equivalents per $\mathrm{ml}(\log (\mathrm{ge} / \mathrm{ml}))$ for a single person during the study period. Points along the horizontal axis represent negative tests. Time is indexed in days since the minimum recorded $\mathrm{Ct}$ value (maximum viral concentration). Lines depict 100 draws from the posterior distribution for each person's viral trajectory. 

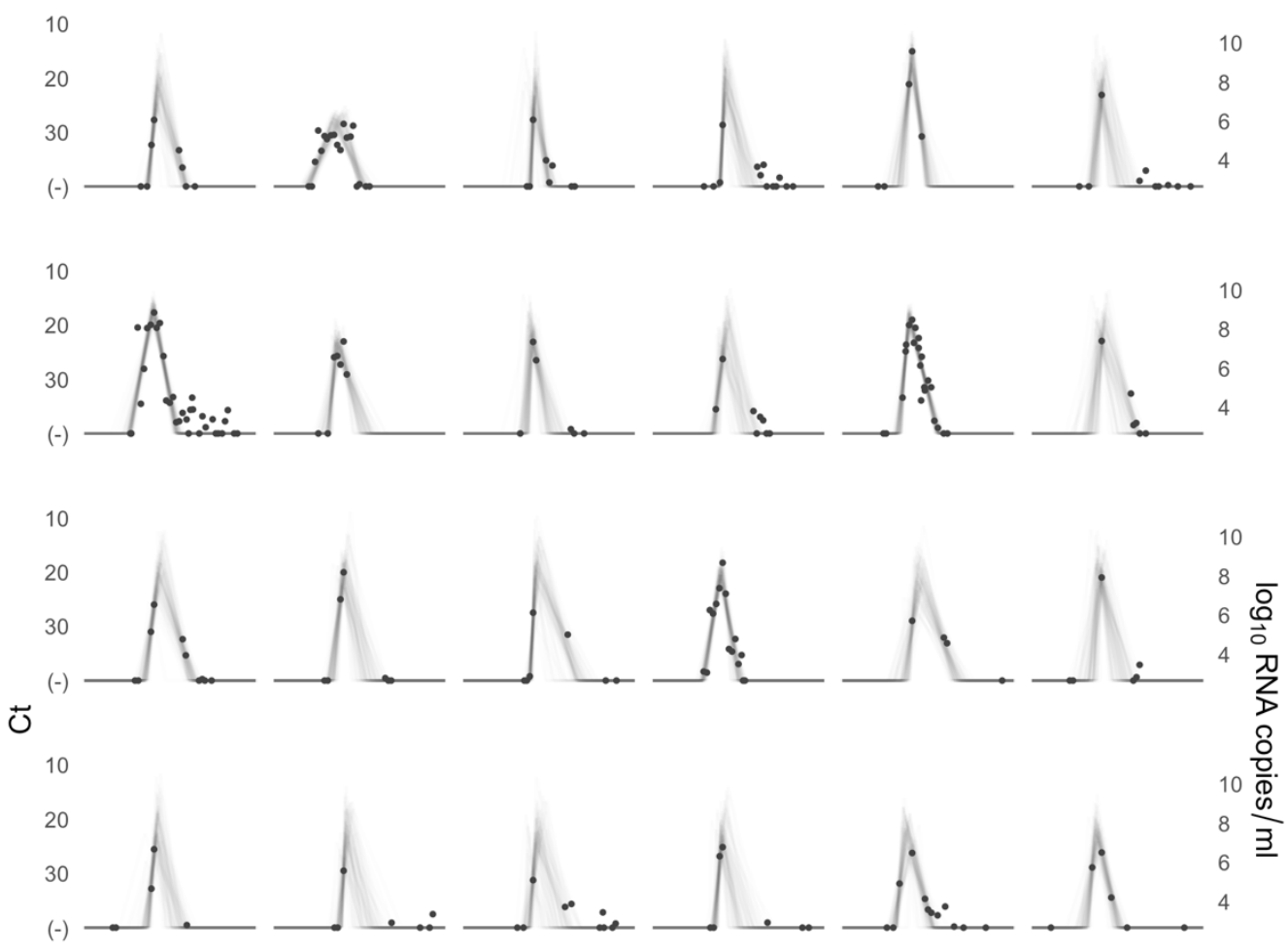

- Unvaccinated
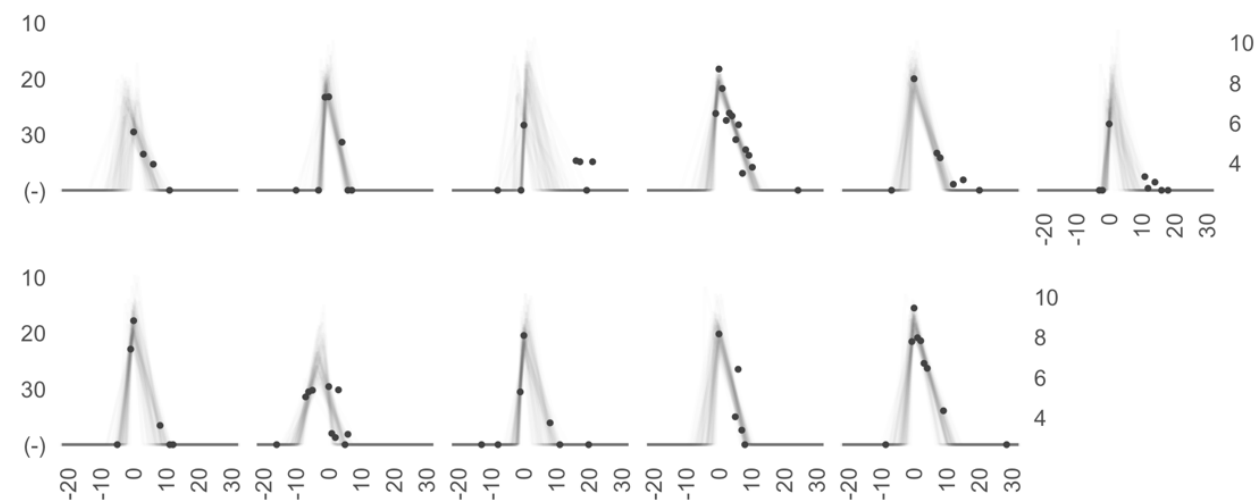

Time since min Ct (days)

Supplementary Figure 7. Ct values and estimated trajectories for SARS-CoV-2 infections in unvaccinated individuals (3/4). Each pane depicts the recorded Ct values (points) and derived log-10 genome equivalents per $\mathrm{ml}(\log (\mathrm{ge} / \mathrm{ml}))$ for a single person during the study period. Points along the horizontal axis represent negative tests. Time is indexed in days since the minimum recorded $\mathrm{Ct}$ value (maximum viral concentration). Lines depict 100 draws from the posterior distribution for each person's viral trajectory. 
medRxiv preprint doi: https://doi.org/10.1101/2021.02.16.21251535; this version posted August 25, 2021. The copyright holder for this preprint (which was not certified by peer review) is the author/funder, who has granted medRxiv a license to display the preprint in perpetuity.

It is made available under a CC-BY-NC-ND 4.0 International license .
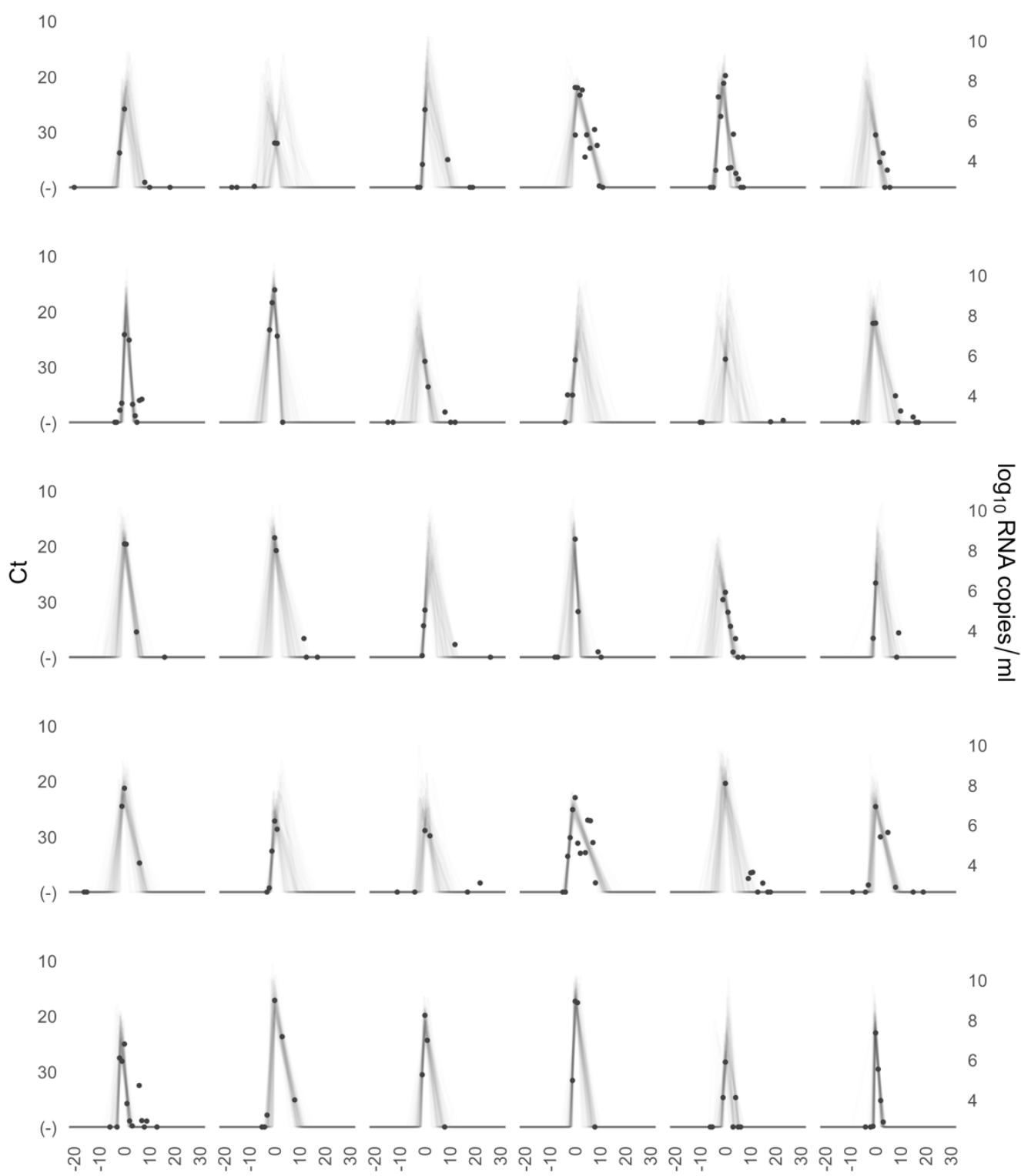
Time since min Ct (days)

Supplementary Figure 8. Ct values and estimated trajectories for SARS-CoV-2 infections in unvaccinated individuals (4/4). Each pane depicts the recorded Ct values (points) and derived log-10 genome equivalents per $\mathrm{ml}(\log (\mathrm{ge} / \mathrm{ml}))$ for a single person during the study period. Points along the horizontal axis represent negative tests. Time is indexed in days since the minimum recorded $\mathrm{Ct}$ value (maximum viral concentration). Lines depict 100 draws from the posterior distribution for each person's viral trajectory. 
medRxiv preprint doi: https://doi.org/10.1101/2021.02.16.21251535; this version posted August 25, 2021. The copyright holder for this preprint (which was not certified by peer review) is the author/funder, who has granted medRxiv a license to display the preprint in perpetuity.

It is made available under a CC-BY-NC-ND 4.0 International license .
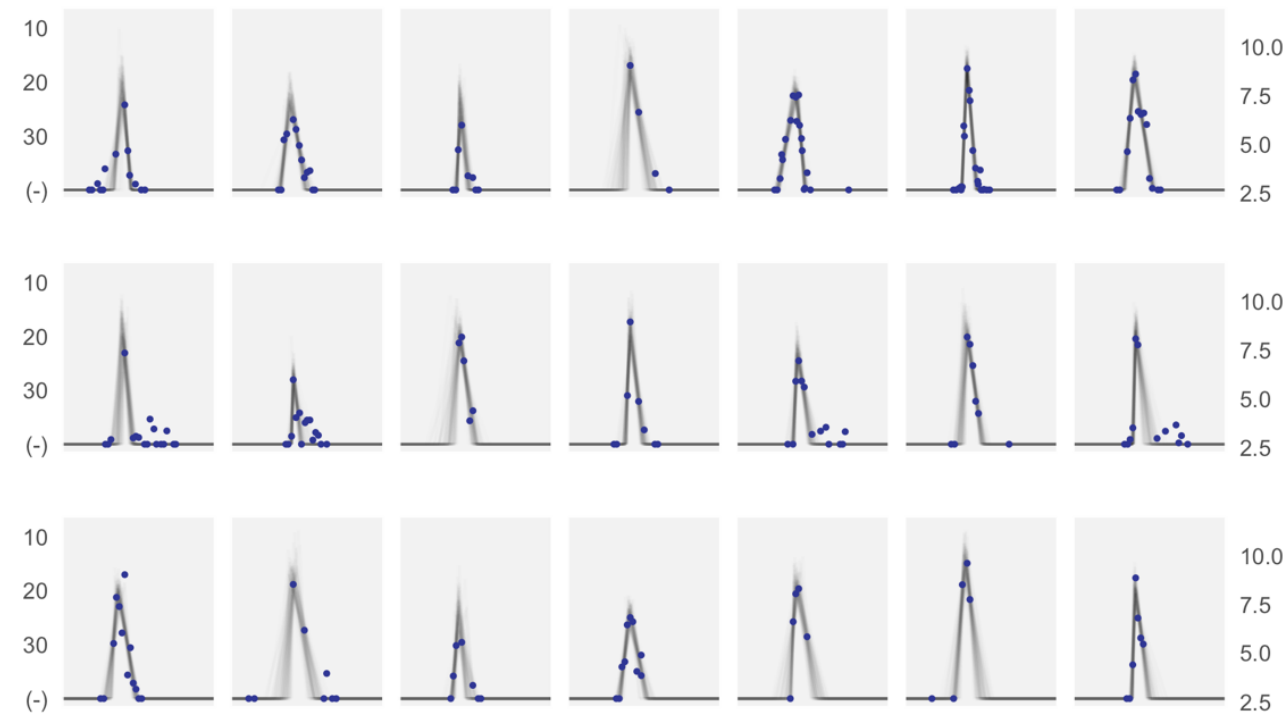

$\overleftarrow{0}$
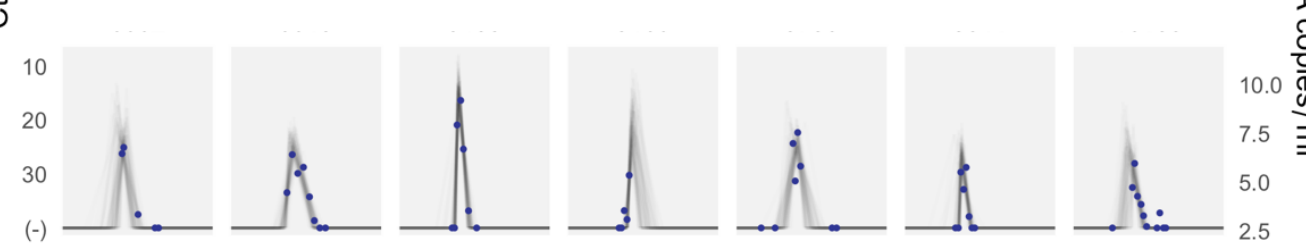

- Vaccinated

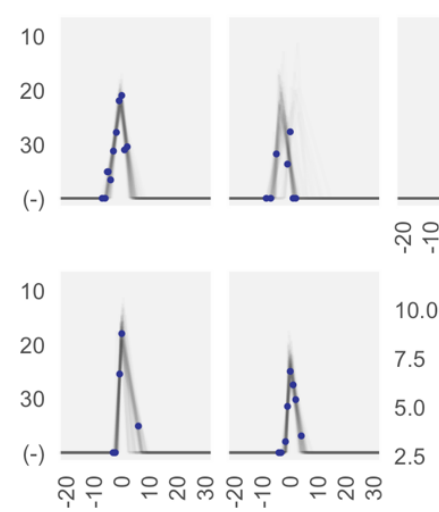

Supplementary Figure 9. Ct values and estimated trajectories for SARS-CoV-2 infections in vaccinated individuals. Each pane depicts the recorded Ct values (points) and derived log-10 genome equivalents per $\mathrm{ml}(\log (\mathrm{ge} / \mathrm{ml}))$ for a single person during the study period. Points along the horizontal axis represent negative tests. Time is indexed in days since the minimum recorded $\mathrm{Ct}$ value (maximum viral concentration). Lines depict 100 draws from the posterior distribution for each person's viral trajectory. Shaded boxes denote breakthrough infections. 
medRxiv preprint doi: https://doi.org/10.1101/2021.02.16.21251535; this version posted August 25, 2021. The copyright holder for this preprint (which was not certified by peer review) is the author/funder, who has granted medRxiv a license to display the preprint in perpetuity.

It is made available under a CC-BY-NC-ND 4.0 International license .

A) Peak viral concentration

B) Proliferation time
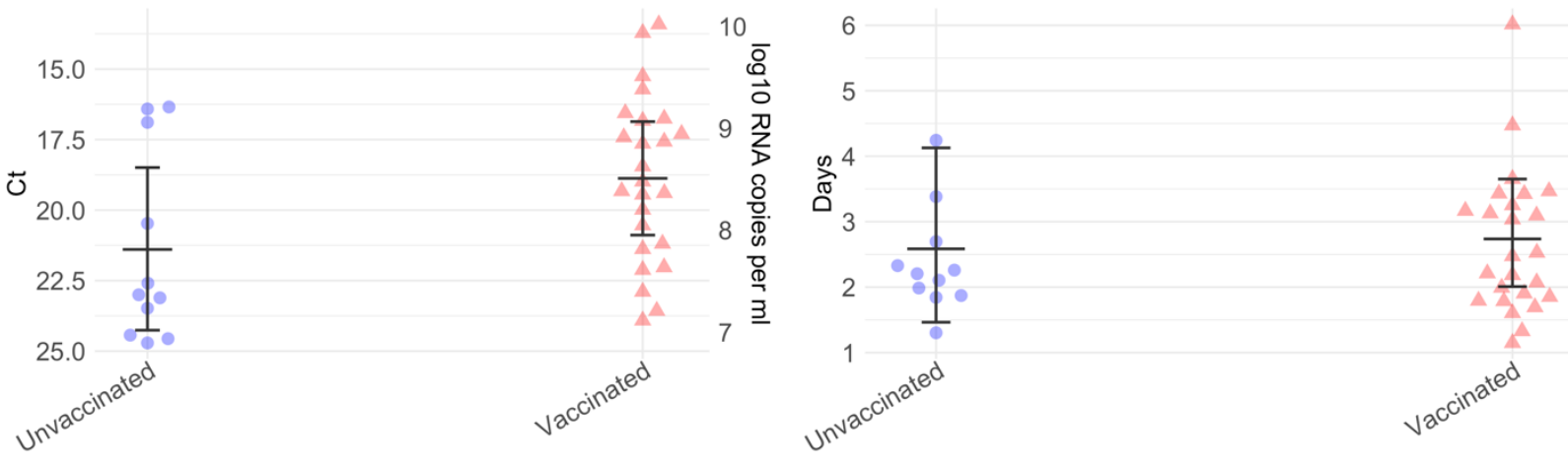

C) ${ }_{12.5}$ Clearance time

D) Acute infection duration

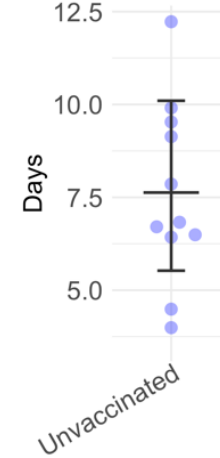

Supplementary Figure 10. Estimated viral trajectory parameters for vaccinated and unvaccinated individuals infected with SARS-CoV-2 variant delta. Individual posterior means (points) with population means and $95 \%$ credible intervals (hatched lines) for (A) the peak viral concentration, (B) the proliferation duration, $(C)$ the clearance duration, and (D) the total duration of acute infection for unvaccinated (blue) and vaccinated (red) individuals infected with delta. Circles denote unvaccinated individuals and triangles denote vaccinated individuals (breakthroughs). The points are jittered horizontally to avoid overlap. Pane (E) depicts the mean posterior viral trajectories for unvaccinated (blue) vs. vaccinated (red) individuals, as specified by the population means and credible intervals in (A)-(D). Solid lines in pane (E) depict the mean posterior viral trajectories and shaded regions represent $95 \%$ credible areas for the mean posterior trajectories. 
medRxiv preprint doi: https://doi.org/10.1101/2021.02.16.21251535; this version posted August 25, 2021. The copyright holder for this preprint (which was not certified by peer review) is the author/funder, who has granted medRxiv a license to display the preprint in perpetuity.

It is made available under a CC-BY-NC-ND 4.0 International license .

A) Peak viral concentration

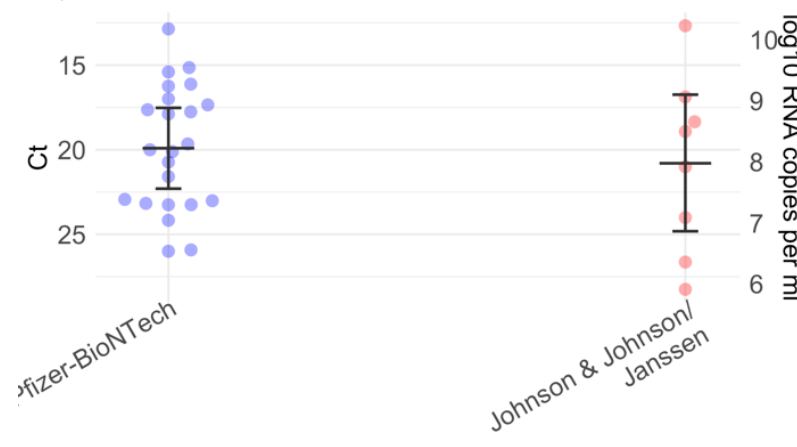

B) Proliferation time

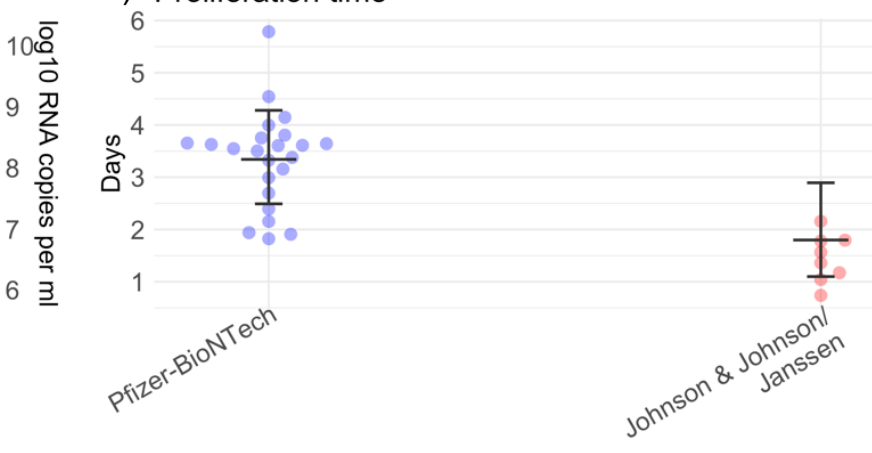

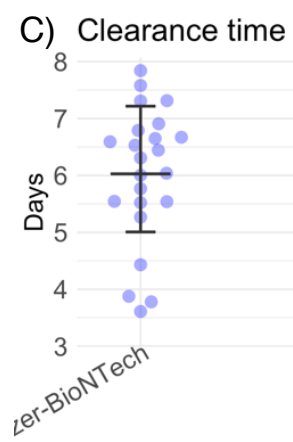

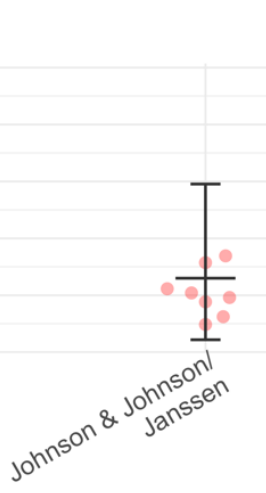

D) Acute infection duration
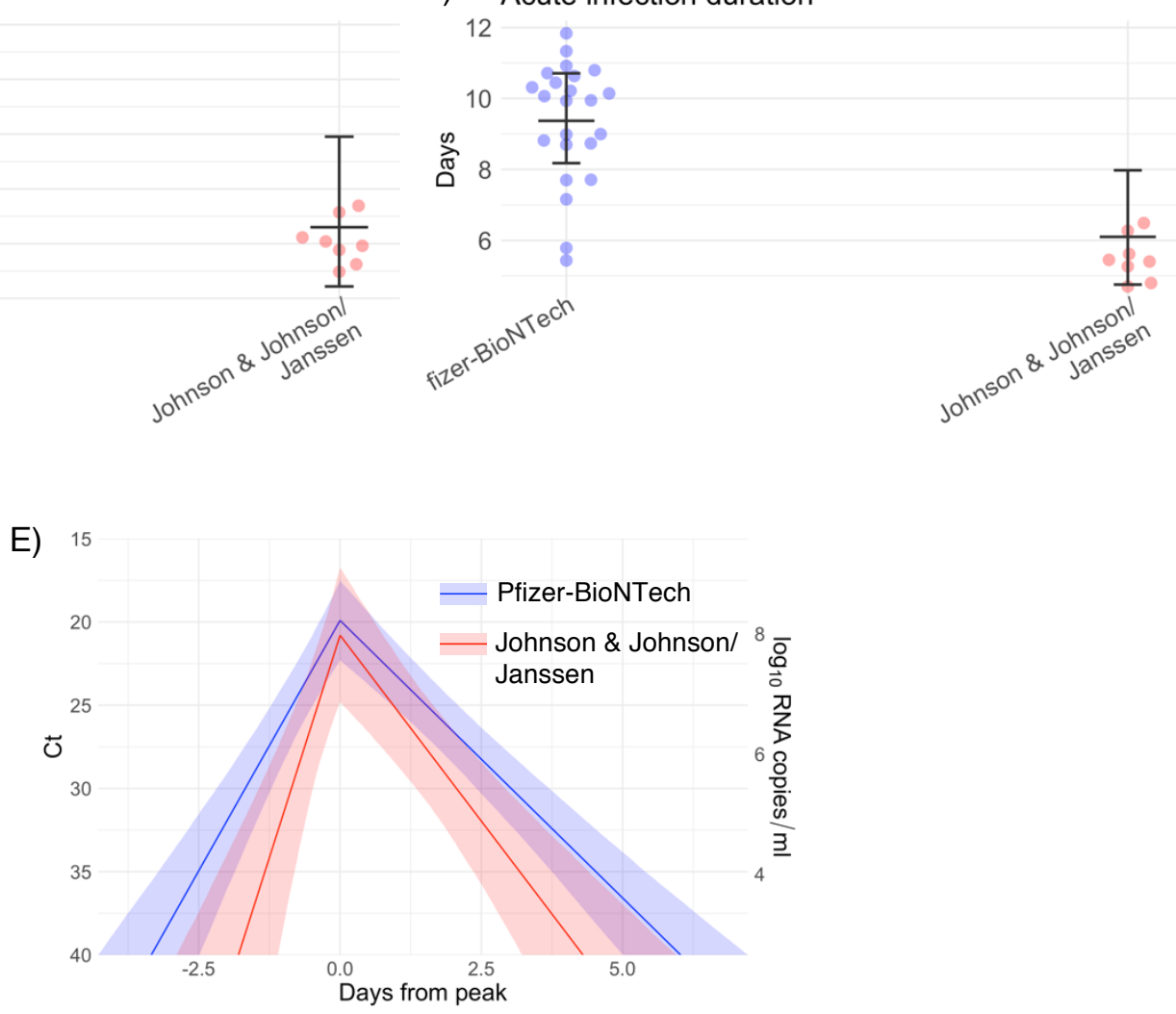

Supplementary Figure 11. Estimated viral trajectory parameters for individuals vaccinated with the Pfizer-BioNTech vaccine vs. the Johnson \& Johnson/Janssen vaccine. Individual posterior means (points) with population means and $95 \%$ credible intervals (hatched lines) for (A) the peak viral concentration, (B) the proliferation duration, (C) the clearance duration, and (D) the total duration of acute infection for breakthrough infections in individuals vaccinated with the Pfizer-BioNTech vaccine (blue) and the Johnson \& Johnson/Janssen vaccine (red). The points are jittered horizontally to avoid overlap. Pane (E) depicts the mean posterior viral trajectories for breakthrough infections in individuals vaccinated with the PfizerBioNTech vaccine (blue) vs. the Johnson \& Johnson/Janssen vaccine (red), as specified by the population means and credible intervals in (A)-(D). Solid lines in pane (E) depict the mean posterior viral trajectories and shaded regions represent $95 \%$ credible areas for the mean posterior trajectories. 
medRxiv preprint doi: https://doi.org/10.1101/2021.02.16.21251535; this version posted August 25, 2021. The copyright holder for this preprint (which was not certified by peer review) is the author/funder, who has granted medRxiv a license to display the preprint in perpetuity.

It is made available under a CC-BY-NC-ND 4.0 International license .

696

697
A)

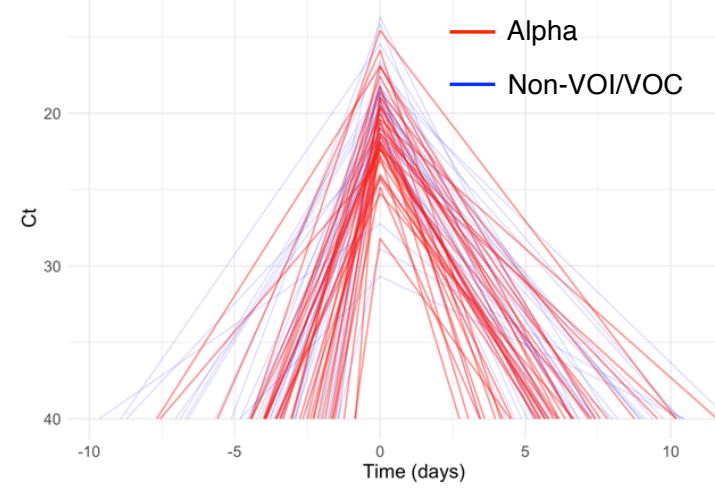

B)
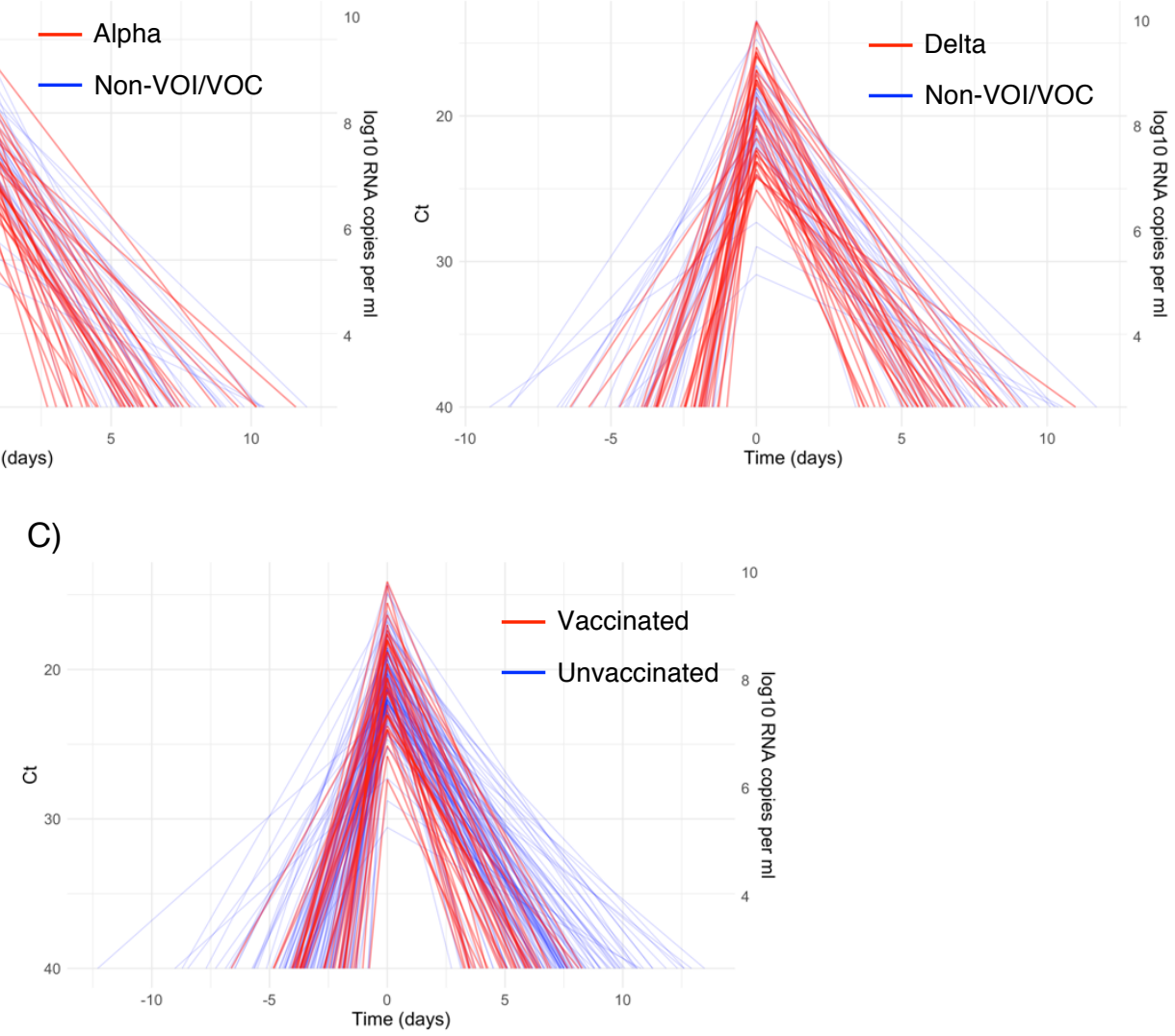

Supplementary Figure 12. Mean posterior viral trajectories for each person. Pane $(A)$ depicts alpha infections (red) against non-VOI/VOC infections (blue). Pane (B) depicts delta infections (red) against nonVOI/VOC infections (blue). Pane (C) depicts infections in vaccinated people (red) against unvaccinated people (blue). Trajectories are aligned temporally to have the same peak time. 
medRxiv preprint doi: https://doi.org/10.1101/2021.02.16.21251535; this version posted August 25, 2021. The copyright holder for this preprint (which was not certified by peer review) is the author/funder, who has granted medRxiv a license to display the preprint in perpetuity.

It is made available under a CC-BY-NC-ND 4.0 International license.

\section{A) Peak viral concentration}

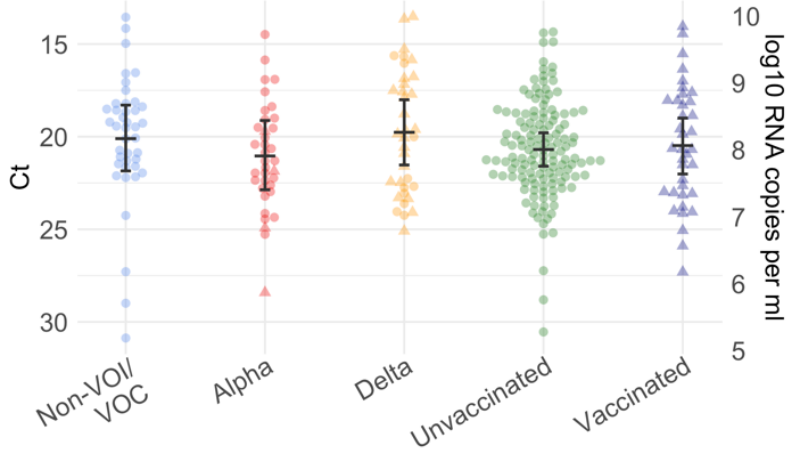

C) Clearance time

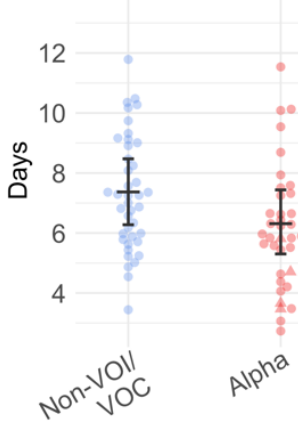

710

711

712

713

E) 15

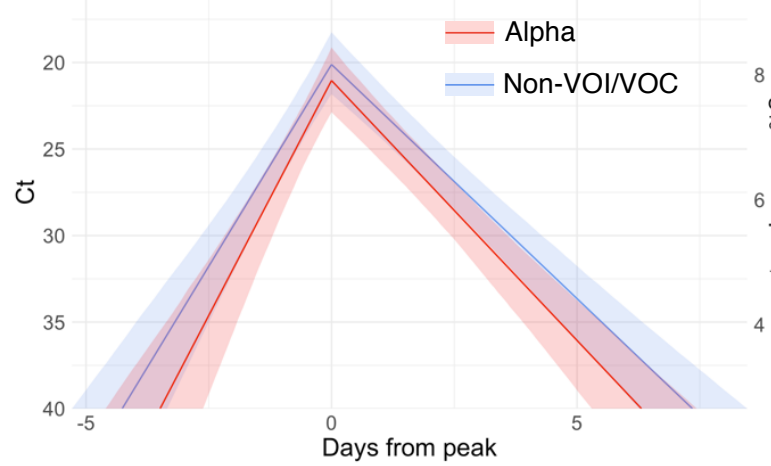

G) 15

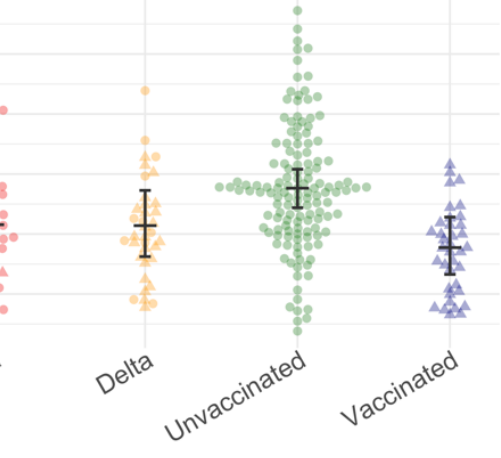

Unvaccinated
B) Proliferation time

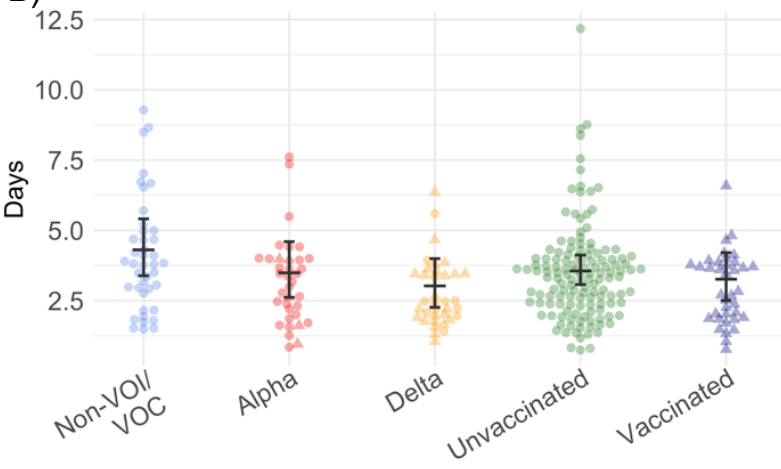

D) Acute infection duration

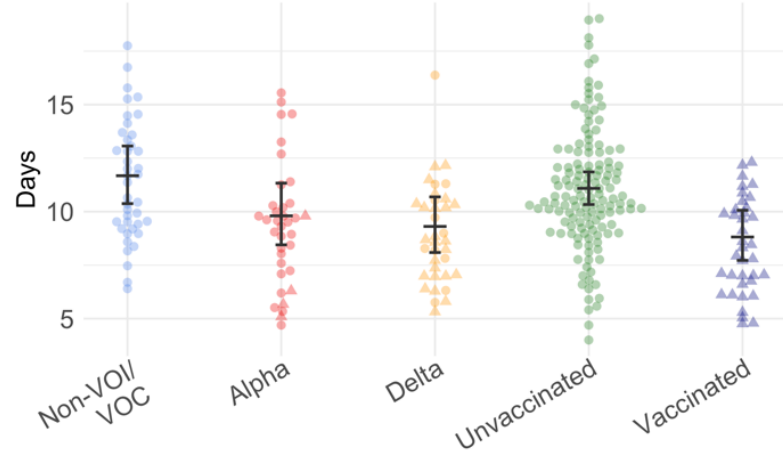

A Vaccinated (breakthrough)

F) ${ }_{15}$
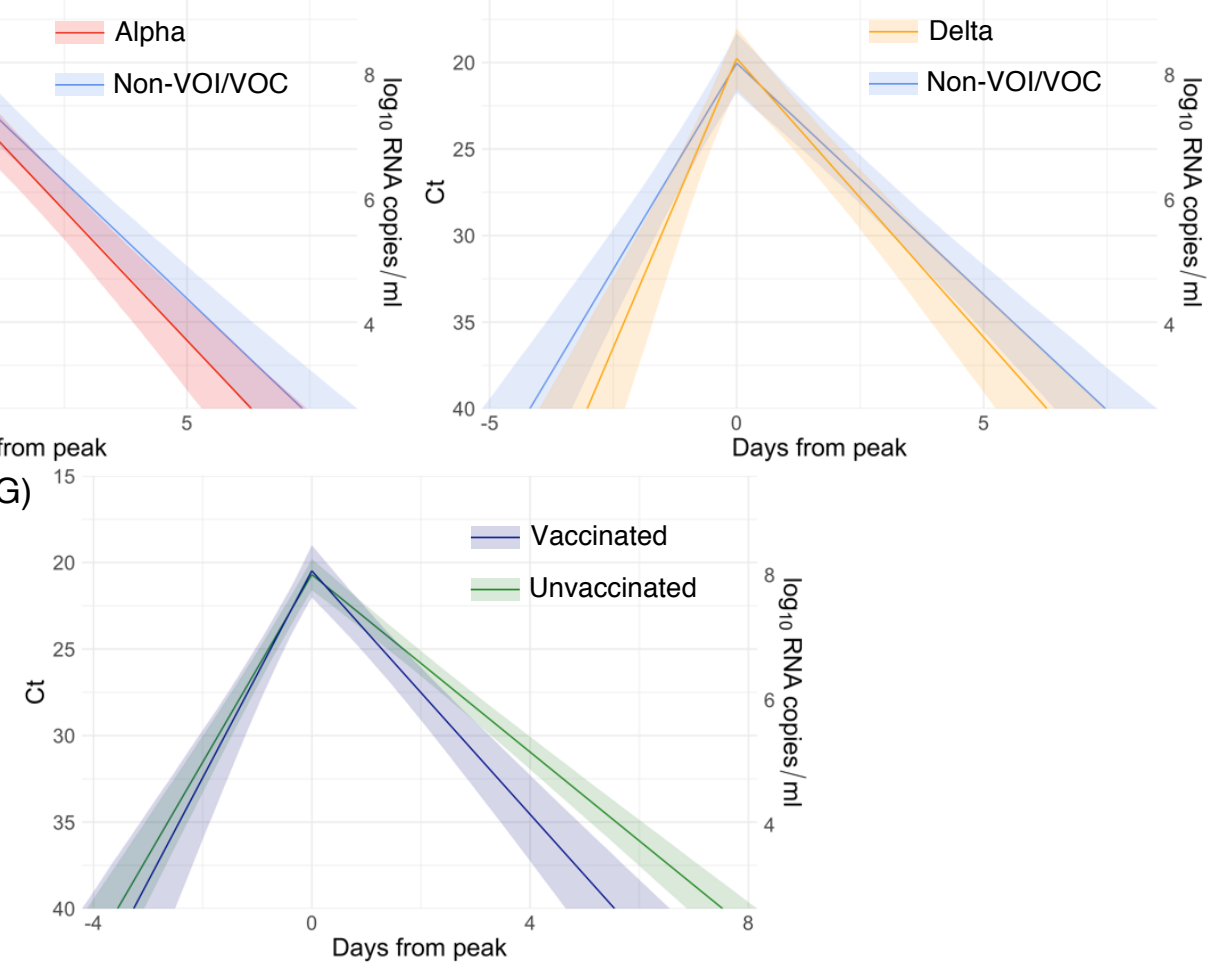
medRxiv preprint doi: https://doi.org/10.1101/2021.02.16.21251535; this version posted August 25, 2021. The copyright holder for this preprint (which was not certified by peer review) is the author/funder, who has granted medRxiv a license to display the preprint in perpetuity.

It is made available under a CC-BY-NC-ND 4.0 International license.

Supplementary Figure 13. Estimated viral trajectory parameters for SARS-CoV-2 infections by variant and vaccination status using uninformative priors. Individual posterior means (points) with population means and $95 \%$ credible intervals (hatched lines) for $(A)$ the peak viral concentration, $(B)$ the proliferation duration, $(C)$ the clearance duration, and (D) the total duration of acute infection for individuals infected with a non-VOI/VOC (blue), alpha (red), or delta (purple), and for individuals who were unvaccinated (green) or vaccinated (maroon). Circles denote unvaccinated individuals and triangles denote vaccinated individuals (breakthroughs). The points are jittered horizontally to avoid overlap. Solid lines in panes (E)-(F) depict the mean posterior viral trajectories for alpha $(E, r e d)$ and delta $(F$, purple) infections respectively relative to non-VOI/VOC infections (blue), as specified by the population means and credible intervals in (A)-(D). Solid lines in pane $(G)$ depict the mean posterior viral trajectory for vaccinated (maroon) relative to unvaccinated (green) individuals. The shaded regions in $(E)-(G)$ represent $95 \%$ credible areas for the mean population trajectories. Priors were informed by a previous analysis and are defined in Eq. (S10). 
medRxiv preprint doi: https://doi.org/10.1101/2021.02.16.21251535; this version posted August 25, 2021. The copyright holder for this preprint (which was not certified by peer review) is the author/funder, who has granted medRxiv a license to display the preprint in perpetuity.

It is made available under a CC-BY-NC-ND 4.0 International license.

A) Peak viral concentration

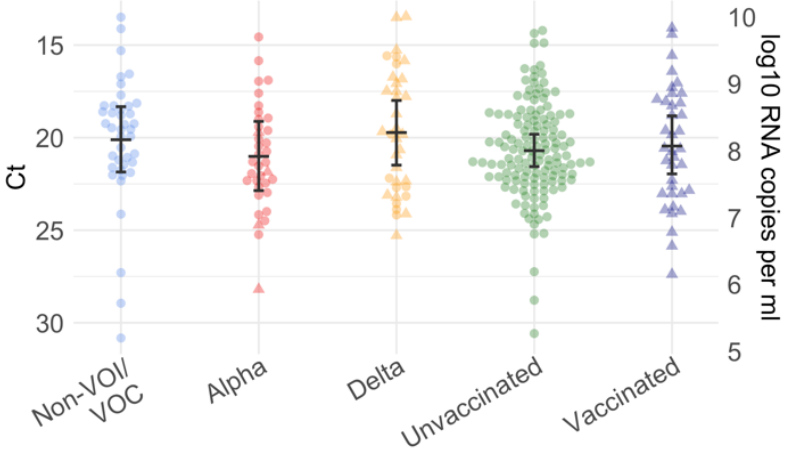

C) Clearance time

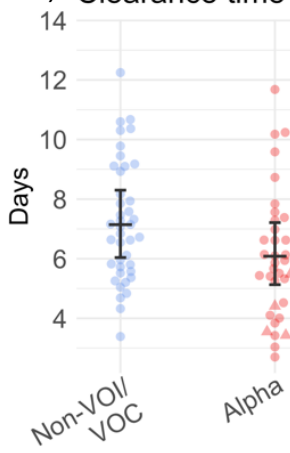

731

732

733

E)

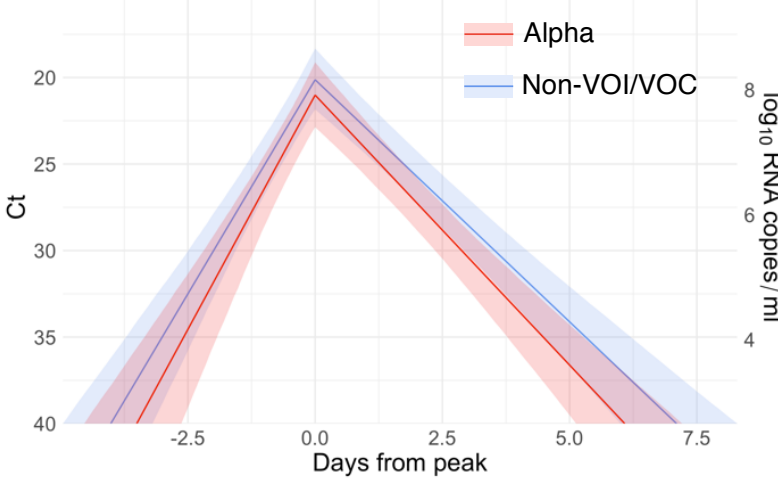

B) Proliferation time

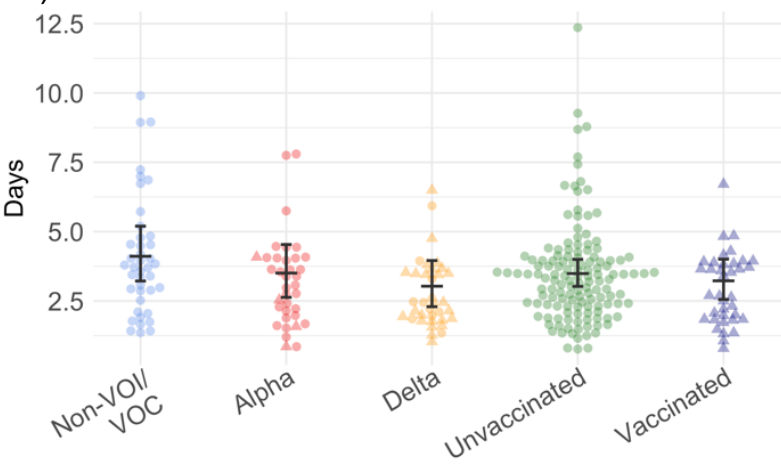

D) Acute infection duration

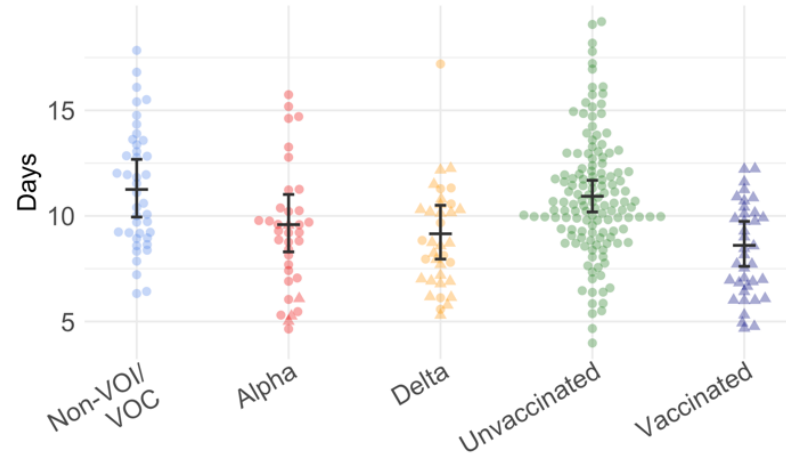

A Vaccinated (breakthrough)

F)

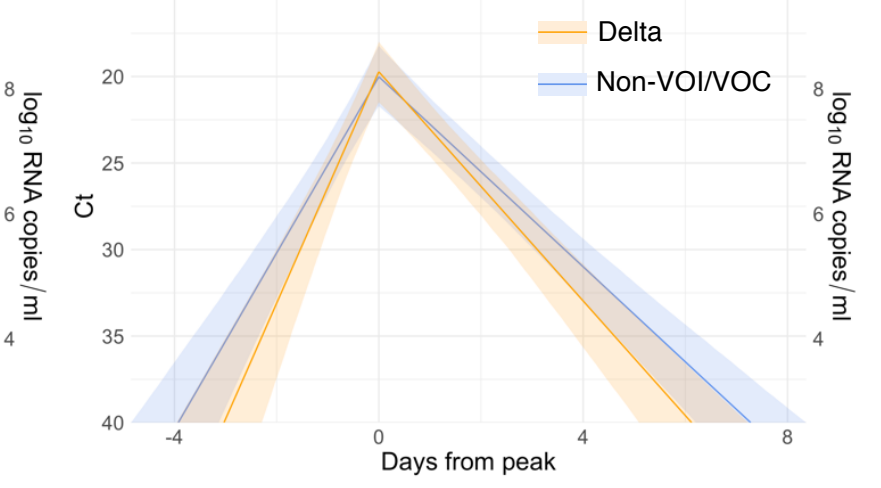

G) 15

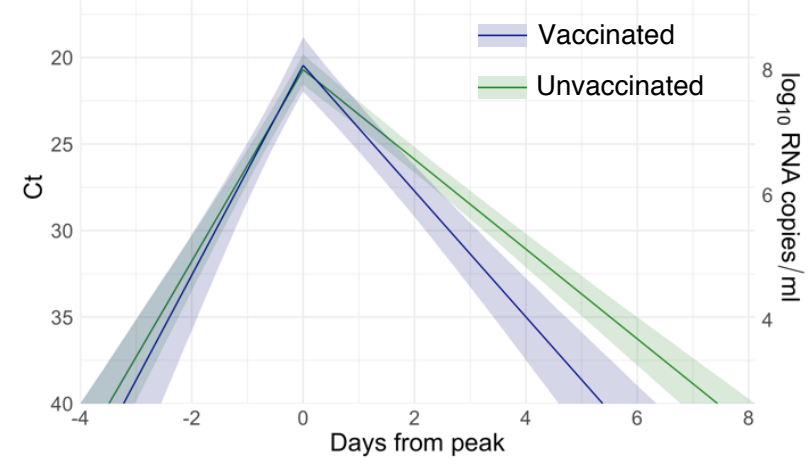


medRxiv preprint doi: https://doi.org/10.1101/2021.02.16.21251535; this version posted August 25, 2021. The copyright holder for this preprint (which was not certified by peer review) is the author/funder, who has granted medRxiv a license to display the preprint in perpetuity.

It is made available under a CC-BY-NC-ND 4.0 International license.

Supplementary Figure 14 Estimated viral trajectory parameters for SARS-CoV-2 infections by variant and vaccination status using biased (low) priors. Individual posterior means (points) with population means and $95 \%$ credible intervals (hatched lines) for (A) the peak viral concentration, (B) the proliferation duration, $(C)$ the clearance duration, and $(D)$ the total duration of acute infection for individuals infected with a non-VOI/VOC (blue), alpha (red), or delta (purple), and for individuals who were unvaccinated (green) or vaccinated (maroon). Circles denote unvaccinated individuals and triangles denote vaccinated individuals (breakthroughs). The points are jittered horizontally to avoid overlap. Solid lines in panes (E)-(F) depict the mean posterior viral trajectories for alpha (E, red) and delta $(F$, purple) infections respectively relative to non-VOI/VOC infections (blue), as specified by the population means and credible intervals in (A)-(D). Solid lines in pane $(G)$ depict the mean posterior viral trajectory for vaccinated (maroon) relative to unvaccinated (green) individuals. The shaded regions in (E)-(G) represent $95 \%$ credible areas for the mean population trajectories. Priors were chosen to be unrealistically low and are defined in Eq. (S11). 